
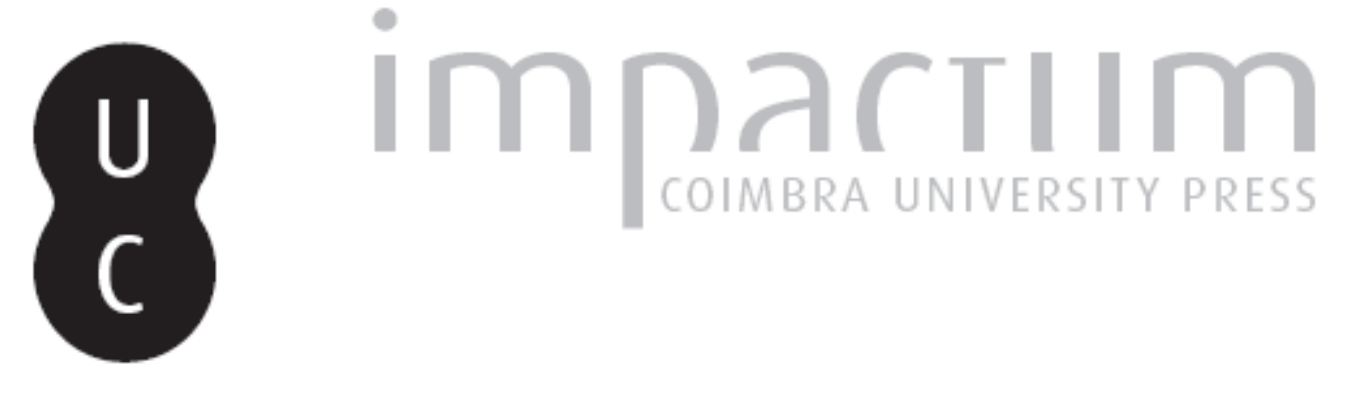

\title{
Morte, memória e piedade barroca
}

\section{Autor(es): $\quad$ Araújo, Ana Cristina Bartolomeu}

Publicado por: Imprensa da Universidade de Coimbra

URL persistente:

http://hdl.handle.net/10316.2/42914

DOI:

https://doi.org/10.14195/2183-8925_11_7

Accessed : $\quad$ 26-Apr-2023 13:05:20

A navegação consulta e descarregamento dos títulos inseridos nas Bibliotecas Digitais UC Digitalis, UC Pombalina e UC Impactum, pressupõem a aceitação plena e sem reservas dos Termos e Condições de Uso destas Bibliotecas Digitais, disponíveis em https://digitalis.uc.pt/pt-pt/termos.

Conforme exposto nos referidos Termos e Condições de Uso, o descarregamento de títulos de acesso restrito requer uma licença válida de autorização devendo o utilizador aceder ao(s) documento(s) a partir de um endereço de IP da instituição detentora da supramencionada licença.

Ao utilizador é apenas permitido o descarregamento para uso pessoal, pelo que o emprego do(s) título(s) descarregado(s) para outro fim, designadamente comercial, carece de autorização do respetivo autor ou editor da obra.

Na medida em que todas as obras da UC Digitalis se encontram protegidas pelo Código do Direito de Autor e Direitos Conexos e demais legislação aplicável, toda a cópia, parcial ou total, deste documento, nos casos em que é legalmente admitida, deverá conter ou fazer-se acompanhar por este aviso.

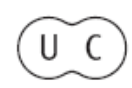


REVISTA DE HISTÓRIA DAS IDEIAS 11

\section{CULTURA POLÍTICA MENTALIDADES}

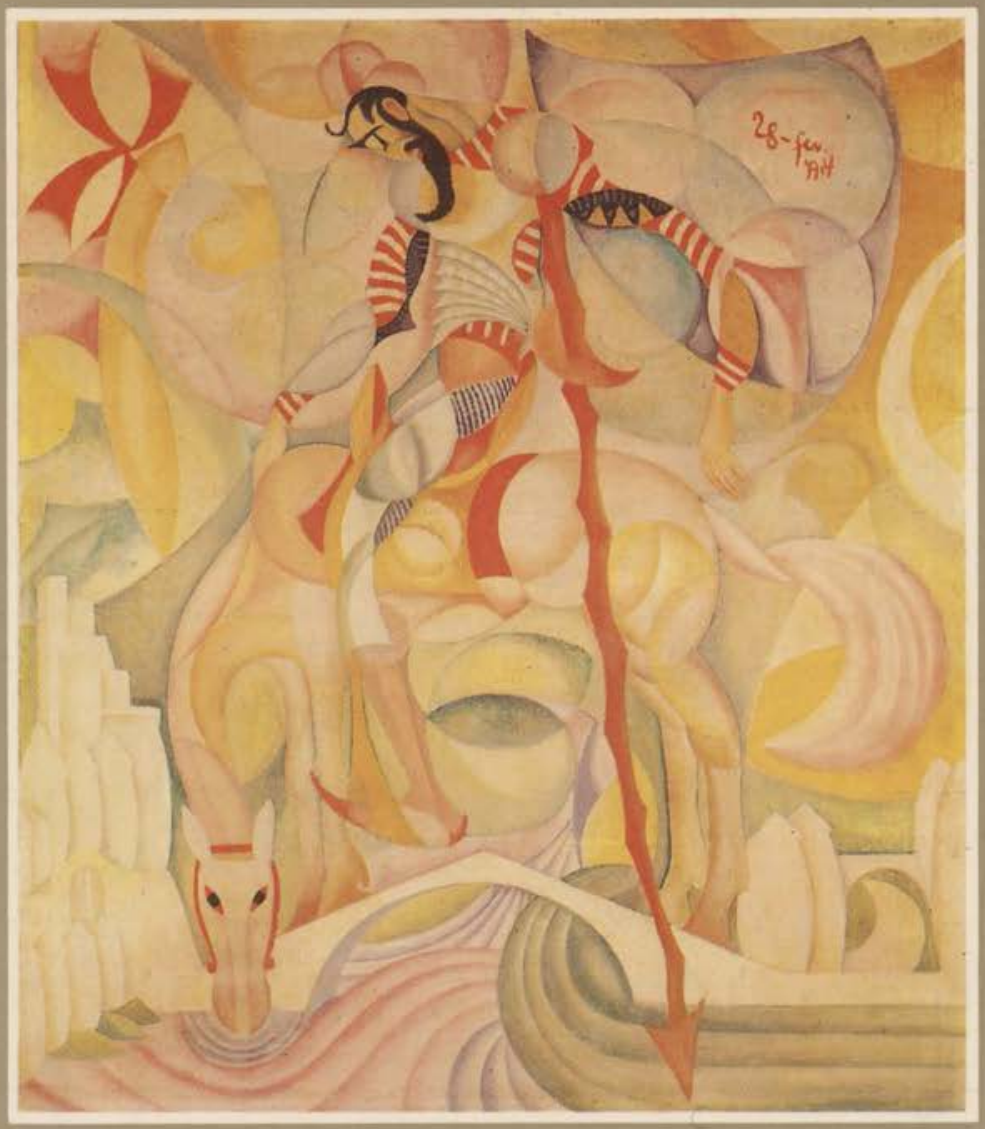

INSTITUTO DE HISTORIA E TEORIA DAS IDEIAS FACULDADE DE LETRAS 


\title{
MORTE, MEMÓRIA E PIEDADE BARROCA
}

\begin{abstract}
"Antes era valido acusar a quienes historiaban el pasado, de consignar únicamente las 'gestas de los reyes'. Hoy día ja no lo es, pues cada vez se investiga más sobre lo que ellos callaron, expurgaron o simplemente ignoraron....».
\end{abstract}

Carlo Ginzburg, El Queso y los Gusanos. El cosmos, según un molinero del siglo XVI.

Em plena mundividência barroca, o requiem pelo monarca era sempre ocasião de um cerimonial aparatoso e espectacular. A morte do rei era configurada como um último rito de submissão colectiva e marcava o início da representação da história feita homem, do grande e singular herói, numa palavra, do homem valor. Tal como no cerimonial das entradas régias, a morte, com todo o aparato que a rodeia, assumia o sentido da "saída régia» ${ }^{1}$ ). Não o da abdicação do poder mas o da sua investidura fantástica pela memória. Através da função maior do espectáculo, isto é, da cristalização do pensar e do sentir de quem nele participava, a sociedade erigia o luto em manifestação póstuma de fidelidade. do I.N.I.C.

* Faculdade de Letras da Universidade de Coimbra, Bolseira

(1) Sobre a evolução formal e estrutura simbólica das entradas régias vide, Ana Maria A̧lves, As Entradas Régias Portuguesas, Lisboa, Livros Horizonte, s.d. Embora para período anterior, é a este respeito paradigmática, logo pela sua legenda ou divisa, a morte de D. João I, Rei da Boa Memória. Está hoje claramente comprovada a importância que o momento da sua eleiçẫo teve na estratégia de perpetuação do rei na memória da Nação. Por isso, a data que convencionalmente se fixou para a sua morte é a mesma que comemora a vitória de Aljubarrota e o aniversário da ida a Ceuta. Vide Armindo de Sovsa, $A$ morte de $D$. João $I$. (Um tema da propaganda dinástica), Porto, Centro de Estudos Humanísticos, 1984. 


\section{Exemplaridades do quotidiano}

No edifício simbólico que se ergue sobre a túmulo do monarca precipita-se um imaginário popular e aristocrático perpassado por cenas de morte e violência. Cenas de um quotidiano marcado pela exibição da morte anónima, do homem comum, do cortesão, do santo e do mártir. A tudo isto se sobrepõe a alegoria da vida e da morte construída e fruída por multidões frenéticas e entusiastas. Referimo-nos ao auto da fé e à tourada.

Recriando a tradição cavaleiresca, a tourada atinge grande riqueza ritual e formal no século XVIII $\left({ }^{2}\right)$. Espectáculo principesco e popular, a tourada elege o animal, o touro que destina ao martírio ou à morte sangrenta, para evidenciar que tal como o sangue enaltece os padrões da honra social, também o espectáculo da morte cria a ilusão festiva e provisória da vida. Aqui, mais do que a festa da vida, celebra-se a ilusão da vida que vence provisoriamente a morte e por ela acaba vencida $\left({ }^{(}\right)$.

Ao contrário da luta sem tréguas da cultura contra a natureza que a tourada também poderá representar, o auto da fé configura o sentido trágico da aventura religiosa do homem moderno.

$\mathrm{Na}$ época em que nos situamos, entre 1707 e 1750, que corresponde ao longo período de governação de D. João V e à vigência do inquisidor-geral D. Nuno da Cunha Ataíde e Melo, realizaram-se em Lisboa 341 autos da fé particulares

(2) Avultam os textos sobre este tema. Vejam-se entre outros, Relação, verdadeiro extracto e nova em que se descreve a festividade de Touros..., Com exacta narração do aparato da Praça, primor das danças e forma do carro triunfante. Composta por seu author Francisco Felix Fialho, s.l., s.d., Relação Nova do Sumptuoso aparato, com que o Supremo Senado pretende celebrar o primeiro dia da segunda celebridade de Touros, s.1., s.d. Uma das séries mais vultuosas e pormenorizadas de festividades de Touros reporta-nos a 1752, à ocasião de aclamação do rei D. José I. Vide, Triduo festival.... Nas tardes de combate de Touros no Terreiro do Paço a 28 de Agosto, 4 e 11 de Setembro de 1752.... Lisboa, na Officina de Manuel da Silva, 1752; Triduo Festival Segundo.... Se repetio nas tardes de 18 e 26 de Setembro, e 2 de Outubro deste anno de 1752, Lisboa, 1752, Relaçam Nova do primeiro dia de Touros.... Noticia certa do succedido, das Danças. Carros Triunfantes, Cavalleiros, $e$ dos divertimentos emtermiados, Lisboa, Composto por Luiz Lazaro Leitam, 1752.

(8) Cf. Bartolomé Bennassar, L'Homme Espagnol. Attitudes et mentalités du XVI* au XIX* siècle, Paris, Librairie Hachette, 1975, pp. $124-130$. 
e 28 autos da fé públicos, sendo a frequência destes bienal $\left({ }^{4}\right)$. Em 64 dos 369 autos da fé realizados saíram penitenciados, excluindo o número elevado de abjurações - que tinham sempre uma expressão edificante e exemplar - cerca de 2300 pessoas, sendo destas relaxadas em carne perto de 200, numa percentagem um pouco inferior a $10 \%$ do volume de penitenciados $\left({ }^{5}\right)$. Número sem grande expressão no tecido demográfico mas que preenchia um lugar importante no imaginário social da cidade. $\mathrm{O}$ mesmo se diga dos autos públicos realizados no largo do Rossio e até mesmo dos que se desenrolavam na igreja de S. Domingos e no palácio da Inquisição, com menor publicidade, mas não totalmente de portas fechadas à cidade, pois o seu anúncio nas igrejas, com quinze dias de antecedência, e a complexa linguagem dos sinos em dias de auto, mobilizavam sempre a atenção da população. Como nota António José Saraiva, "com o tempo e a experiência o auto-de-fé acabou por ser um grande e pomposo espectáculo com um cerimonial minuciosamente regulamentado. a que assistiam as autoridades supremas, frequentemente o rei em pessoa, e que movimentava toda a cidade como as maiores festividades públicas» $\left({ }^{6}\right)$.

Com ou sem procissão de penitenciados, o auto podia durar largas horas ou até mais do que um dia. Em Lisboa, toda a acção se concentrava nas duas principais praças da cidade. o Rossio e o Terreiro do Paço. Era aqui que, tradicionalmente, o cadafalso do auto da fé era armado $\left({ }^{7}\right)$. $O$ espaço

(4) Números fornecidos por Maria Luisa Braga. A Inquisição na Epoca de D. Nuno da Cunha de Ataíde e Melo (1707-17.5ח). I e II. Separatas da Revista Cultura, História e Filosofia, 1982 e 1983. Os dados apresentados por Maria Luisa Braga foram elaborados a partir da colecção de Listas Impressas e Manuscritas dos autos da fé núblicos e particulares das Inquisições de Lisboa, Coimbra e Evora. corrigidas e anotadas por António Joaquim Moreira. (B.N.L. Cod. 863, 864, 865). Cf. Fortunato de Almeida, História da Igreja em Portugal, vol. IV, Porto-Lisboa, Livraria Civilizacão. 1971, (9." edicão) pp. 286-318. e João Lúcio de Azevedo. História dos Cristãos Novos Portugueses, Livraria Clássica Editora, 1975, pp. 331-345.

(5) Valores obtidos a partir da "Relação de feitos celebrados pela Inquisição de Lisboa" apresentada por Fortunato de Almeida, ob. cit., vol. IV, pp. 293-295.

(8) António José Saraiva, Inquisição e Cristãos-Novos, Porto, Editorial Inova, 1969 , p. 148.

(7) A propósito do espaço da condenação, refira-se que a execução dos relaxados em carne ocorria fora do recinto do cadafalso, ou seja, na zona popular da Ribeira Velha, confinante com o bairro da Alfama.

A partir da planta do cadafalso do auto da fé elaborada por Mateus Couto, em 1634, Francisco Bethencourt analisa o espaço e 
onde a condenação tinha lugar era também simbólico. A presença do palácio real, onde o rei como espectador privilegiado assistia, assinalava o limite ou a fronteira de um espectáculo essencialmente religioso. Em frente, o estuário do Tejo abria-se ao mar, que no imaginário social continuava a ser também caminho para a morte e trânsito de glória. A associaçáo é expressa de torma original e inequívoca em títulos de obras de preparação da morte como estes: Descripçam do Tormentoso C'abo da Enganosa Esperança A Hora da Morte de Nicolau Fernandes Collares (1718) e Para o Golfo da Vida no Estreito Passo da Morte de Luis Botelho Froes de Figueiredo (1713).

No seio de um catolicismo hegemónico e expansivo, a auto da fé valia como rito consagrador de uma instituição vulgarmente definida pela sua eficácia ritual - Santo Ofício. Por isso, durante mais de dois séculos, permitiu alimentar um imaginário social perpassado pelos fantasmas do medo e da insegurança $\left({ }^{8}\right)$.

Culminando um processo construído a partir da denúncia anónima, procedimento aliás comum a outros tribunais, o auto, sobretudo quando se desenrolava publicamente, era vivido como um momento libertador e purificador em que a nomeação dos acusados e a imolação das vítimas valia como rito mágico de purificação. Um certo espírito mágico ressurge ainda nos ágapes, entre os quais o mais conhecido é o jantar do auto, reservado a um número restrito de deputados, promotores e clérigos, e em que se consumiam grande quantidade e riqueza de iguarias.

O sacrifício repetido do cristão-novo - elemento chave de todos os autos e sobre quem impendia a constante acusação de judaísmo - reforçava o sentido de continuidade da lei e a união da comunidade.

A ocasião permitia igualmente expiar o medo e a profunda desconfiança dos que, a qualquer momento podiam passar de acusadores a acusados. Agindo o seu próprio medo, a população frenética e solidária com o castigo reivindicava a sua intervenção no acto, impondo suplícios próprios, como o uso do tição no rosto das vítimas, recriando pois, através

alguns aspectos do cerimonial dos autos, Inquisição e Controle Social. Separata da Revista História e Critica, Lisboa, 1987. Este estudo é aliás de grande interesse como abordagem preliminar ao poder disciplinar e simbólico da Inquisição portuguesa.

(8) B. Bennassar, "L'Inquisition ou la pédagogie de la peur» in B. Bennassar (dir.), L'Inquisition espagnole, $X V^{\circ}-X I X^{\circ}$ siècle, Paris Hachette, 1979, pp. 105-137. 
do espectáculo, a ilusão de um exercício de justiça executado às suas próprias mãos. Gesto que acarretava a vivência inconsciente e fantasmática da violência e da contestação, isto é, a transformação do acontecimento num rito social indispensável a uma estratégia da ordem e da conservação do poder.

Revestindo, acima de tudo, a importância de momento primordial, numa sociedade profundamente marcada pelo espírito religioso, o auto da fé solenizava, exemplarmente, aos olhos do povo, o carácter imperativo de "acto de inspiração divina", ininteligível e estranho à vontade e à compreensão humana, numa palavra, do acto de fé $\left(^{9}\right)$. Mas este como todos os temas relacionados com a apropriação simbólica, a eficácia ritual e a projecção da Inquisição no imaginário social carecem de estudos mais profundos. Retenhamos, por enquanto, que na grandiosa encenação do castigo e da imolação - gesto que igualmente isentava de dúvidas o poder de interferência do homem na determinação e prefiguracão do seu destino escatológico - se recapitulava a própria lição do quotidiano, isto é, o sentido de uma experiência de vida construída a pensar na morte. Por isso o pequeno teatro da morte individual constantemente se recriava nesta e em outras representações da morte colectiva.

\section{$O$ cerimonial fúnebre na "Sociedade de Corte»}

A cada momento ressurge essa dimensão agónica do homem barroco, em perpétuo conflito com as ameacas do mundo exterior e que ora se exprime em feéricas manifestações de vida, sempre oníricas e ilusórias, ora se arrasta para um pessimismo doloroso e triste $\left({ }^{10}\right)$.

Se a literatura, a arte, o teatro, a liturgia religiosa e a convenção social expressam, de modos diversos, o investi-

(`) Perfilhamos da acepção de sagrado e acto de fé expressos em Mircea Eliade, $O$ mito do Eterno Retorno, Lisboa, Edições 70, 1981, pp. 124-125; idem, O Sagrado e o Profano. A essência das Religiões, Lisboa, Livros do Brasil, s.d.

(10) O quadro geral da cultura e da mentalidade barrocas em que se inserem estes traços de sensibilidade são especialmente tratados por José António Maravall, La Cultura del Barroco. Analisis de uma estructura histórica, Barcelona, Ed. Ariel, 1975; Richard Alewyn, L'Univers du Baroque, Genéve, Genthier, 1964. Santiago Sebastián, Contrarreforma y barroco lecturas iconográficas e iconológicas, Madrid, Alianza Editorial. A revisão crítica da bibliografia sobre 
mento necrófilo da época é na encenação colectiva, e sempre com tremenda publicidade, do fasto fúnebre que se cristaliza a sensibilidade do homem comum face à morte. Sensibilidade fortemente contagiada pela visão do martírio e pela expressão de dor, enfim, por manifestações extremes de "militância religiosa" de inspiração tridentina que muito contribuíram para vulgarizar o lema do individuo prisioneiro da vida terrena e resgatado pela morte, divisa que se impôs num meio claramente familiarizado com a morte.

Nas 40 freguesias que compunham a cidade de Lisboa (11) tornara-se rotineira ou mesmo diária a passagem da tumba da Misericórdia ou das irmandades, pelo menos durante o primeiro quartel do século em que a mortalidade provavelmente se manteve elevada.

Neste quadro. a morte dos grandes, com o seu aparato cerimonial, constituía motivo de atracção popular. Manifestação póstuma de vaidade e prestígio, o desfile fúnebre recapitulava o sentido da distinção social pela exibição de rígidos códigos de etiqueta inspirados na vida da corte. De algum modo, a busca de uma exemplaridade visível no cortejo fúnebre do nobre e do prelado e, consequentemente, os reflexos que esse cerimonial acabou por ter nos obséquios da gente comum, realçam o próprio ethos de uma sociedade de corte, atraída e contaminada pelo poder disciplinar e simbólico da corte $\left({ }^{12}\right)$.

o barroco é apresentada no capítulo de abertura de uma obra recente e com manifesto interesse também para o tema que tratamos, Rui Bebiano, D. João $V$ - Poder e espectáculo, Aveiro, Livraria Estante Editora, 1987. Sobre os discursos e representações da morte barroca vide Michel Vovelle, La mort et l'Occident de 1300 à nos jours, Paris, Gallimard, 1983.

(11) Vide Paulo Dias de Niza, Portugal Sacro-Profano, ou Catalogo Alfabetico de todas as Freguesias dos Reinos de Portugal e Algarves...., Lisboa, Na Officina de Miguel Manescal da Costa, 1767, Parte I, pp. 321-326; Lisboa na 2." metade do Séc. XVIII. (Plantas e Descrições das suas freguesias). Recolha e Indice por Francisco Santana, Lisboa, Publicações Culturais da Câmara Municipal de Lisboa, s.d.; Fernando Portugal e Alfredo de Matos, Lisboa em 1758. Memorias Paroquiais, Lisboa, Publicações Culturais da Câmara Municipal de Lisboa, 1974; Vieira da Silva, Plantas Tipográficas de Lisboa, Lisboa, Câmara Municipal de Lisboa, 1950; Gustavo Sequeira, "A Cidade de D. João V», in Lisboa oito Seculos de História, Publicações comemorativas do $8 .^{\circ}$ Centenário da tomada de Lisboa aos Moiros, Lisboa, Publicações da Câmara Municipal de Lisboa, 1947; idem, ibidem in D. João V, Confe. rências e Estudos Comemorativos do Segundo Centenário da sua morte (1750-1950), Lisboa, Publicações Culturais da Câmara Municipal de Lisboa, 1952.

(12) Norberto Elias, La Société de Cour, Paris, Flammarion, 1985. 
Não é fácil, hoje, reconstituir, em toda a extensão, essas lutuosas manifestações de opulência e piedade. Relatos vagos e breves, repletos de adjectivações e louvores, como epicédios, elogios fúnebres, relações e orações fúnebres, aproximam-nos da ambiência vivida mas dão-nos, sobretudo, uma imagem depurada e idealizada dos seus protagonistas póstumos. Algo de idêntico se passa na iconografia tumular, embora aqui a representação resulte mais precisa e durável. Já a arquitectura perecível e efémera dos catafalcos e mausoléus e outros elementos decorativos indispensáveis à encenação do espectáculo, como panos, tocheiros, caveiras, insígnias e dísticos, embora muito mencionados, não deixaram vestígios e só raramente. se encontram gravados em estampas.

Quanto ao sermonário apesar de ser expressão de uma retórica oralizada, foi abundantemente impresso nos séculos XVII $\epsilon$ XVIII. A tendência para a sua fixação escrita é, desde logo. indicadora de uma prática de leitura cultivada e vulgarizada.

O sermão de inspiração barroca, elemento primordial no fasto fúnebre, apenas confirma uma evolucão mais geral e em que o adorno da linguagem, correspondendo a uma vincada exuberância estética e cerimonial, conflui para acentuar o efeito psicológico da comoção e do deslumbramento. $\mathrm{Na}$ construção desta arquitectura dos sentidos, onde a palavra se plasma no objecto visto ou idealizado. a morte assume, em toda a sua plenitude, o fascínio do «belo-horrível». Não deve pois estranhar-se o recurso, frequente entre os pregadores mais afamados, a uma caveira iluminada que não só servia de suporte visual do sermão como até, por vezes, de interlocutora privilegiada do orador, quando se tratava de demonstrar a caducidade e fragilidade da vida ou de descrever a natureza das penas infernais a que estava sujeito o crente menos avisado. A adaptação deste nível discursivo da liturgia comum aos grandes cerimoniais fúnebres apenas contribui para enfatizar uma mensagem amplamente apreendida e que Michel Vovelle e Jean Delumeau consideram estar no âmago da "pastoral terrorista da morte» $\left({ }^{13}\right)$.

Tomada, portanto, numa acepção ampla, esta retórica da morte barroca atinge o seu ponto culminante na época de D. João V. Mas já na corte de D. Pedro II as pompas fúnebres adquirem grande ressonância social. Logo em 1683 e primeiros meses do ano seguinte, grandiosas manifestações

(13) Jean Delumeau, Le Peché et la Peur. La Culpabilisation en Occident XIII-XVIII siècles, Paris, Fayard, 1983, pp. 375-376. 
de luto conferem manifesto lustre às exéquias da rainha D. Maria Francisca Isabel de Sabóia. Entre outros pregadores, o P. Ratael Bluteau recitou, na Santa Casa da Misericórdia, uma Oração Fúnebre que, à semelhança de outras, correu impressa.

Ainda durante a regência e já no reinado de D. Pedro II, respectivamente em 1673 e 1693, celebraram-se, com solenidade, as exéquias de dois Inquisidores-Gerais, D. Pedro de Lencastre, duque de Aveiro e Veríssimo de Lencastre, tendo sido ambos sepultados no convento da Província da Arrábida, em Lisboa, onde tinham jazigo os duques de Aveiro. Também a morte do Marquês de Távora deu lugar a um cerimonial rígido e organizado a partir da capela real $\left({ }^{14}\right)$.

Uma das expressões mais elevadas do cerimonial fúnebre cortesão paderá ter sido no termo do século XVII, precisamente em 1699, a morte da princesa D. Maria Sofia Isabel de Neuburgo. Nas principais igrejas e conventos de Lisboa e de muitas cidades do país realizaram-se ofícios, erigiram-se cenotáfios e declamaram-se orações fúnebres. Profusão de práticas que é bem reveladora da intensidade dramática e da sobrecarga cénica que a morte dos grandes suscitava.

O macabro, um dos traços fortes da sensibilidade barroca, aflora com alguma intensidade nestas pompas fúnebres. 0 recurso à caveira símbolo «abstracto e acéptico» da morte, é simultaneamente estético e moralizante. da mesma forma que o é a modulação literária e poética do tema da beleza física, aos poucos perdida e, por fim. caída na mais abjecta e horrível imagem. E isso que revelam os prantos poéticos, Queyjas de fermosura contra as Tyranias da parca de João Baptista Ponte que glosa um soneto camoniano, e Eclipse da formusura observados no espelho da saudade de Luis Sequeira Gama, Desposos da Magestade, de Pedro Azevedo ou ainda o Heptaphonon, ou Portico de Sette Vozes de Pascoal Rybeiro Coutinho, para só referir alguns exemplos.

Esta manifestacão de gosto e sensibilidade barrocos só será excedida, à escala pública, com as exéquias do monarca

(14) Oraçam funebre, que disse Frey Luis da Sylva Religioso da Ordem da Sanctissima Trindade, Bispo de Titiopoli, para fazer os Pontificaes da Capella Real...., Nas exequias do Excellentissimo Senhor Marquez de Tavora, s.l., s.d. Esta oração foi publicada por António Rodrigues de Abreu, juntamente com o Compendio Panegyrico da vida do Marquez. Sobre o sentido da celebração da morte dos grandes vide o excelente e pioneiro estudo de Mário Martins, Introdução Histórica à Vivência do Tempo e da Morte, Braga, Livraria Cruz, 1969, vol. II, particularmente capítulo XII. 
D. Pedro II. Em 1706, parafraseando o título da declamação de Pedro de Azevedo Tojal, todo "O Portugal luctuoso chorou a morte do Augustissimo Senhor D. Pedro II". A escala do Império, foi no Brasil, a colónia do ouro, que as solenidades revestiram grande pompa como atesta Sebastião Rocha Pitta no Breve Compendio e narraçam do funebre espetáculo, que na insigne cidade da Bahia, Cabeça de America Portugueza se vio na morte de El-Rei D. Pedro II (1709). Em Lisboa, onde foram erigidos vários cenotáfios. o espectáculo foi patético e solene, tendo tido idêntica repercussão na corte pontífica em Roma.

Aí, na Igreja de Santo António dos Portugueses cuja fachada foi coberta de panos negros, ergueu-se. em 1707, um monumental Castrum Doloris ideado pelo famoso arquitecto italiano Carlos Fontana. que já antes concebera a cenografia dos fastos fúnebres de Leopoldo I, pai da arquiduquesa Maria Ana de Áustria e futura esposa de D. João V.

Parece clara a influência de Bernini na concepção e inspiração decorativa deste Castrum doloris (figura 1). A urna em forma piramidal invertida é figurada suspensa, como que em levitação, ladeada por quatro esqueletos prateados e dourados. Nesta fantasia barroca sobressaem ainda a imaginária rica e cheia de movimento, insígnias e a efígie do rei colocada sobre o catafalco. Encimava-a um baldaquino, em forma de coroa pendente da cúpula da igreja, sobre o qual se erguia uma esfera armilar e uma cruz.

Cada um dos elementos decorativos desta grandiosa máquina fúnebre possuía um significado preciso. No seu conjunto, a estrutura central, que organizava o espaço cénico do fasto fúnebre, impunha-se como uma cena teatral com os panos do baldaquino corridos lateralmente, mostrando o herói em efígie, ladeado por outros actores em pedra. $\mathrm{O}$ movimento das figuras imprimia à representação uma certa carga dramática, que era realçada pela presença dos esqueletos. Um poderoso artifício de luz obtido por centenas de velas e tochas a arder tornava a encenação mais espectacular. $\mathrm{O}$ sermão e a música acentuavam o arrebatamento do olhar.

O cenotáfio de D. João V, erguido cerca de 40 anos mais tarde, em Roma, reproduziria ainda de forma mais ambiciosa e exuberante este modelo. A afinidade de estilo obedece a preocupações e valores que transcendem os meros padrões estéticos. De par com outros indicadores, é paradigma de uma mesma sensibilidade perante a morte. 
Revista de História das Ideias

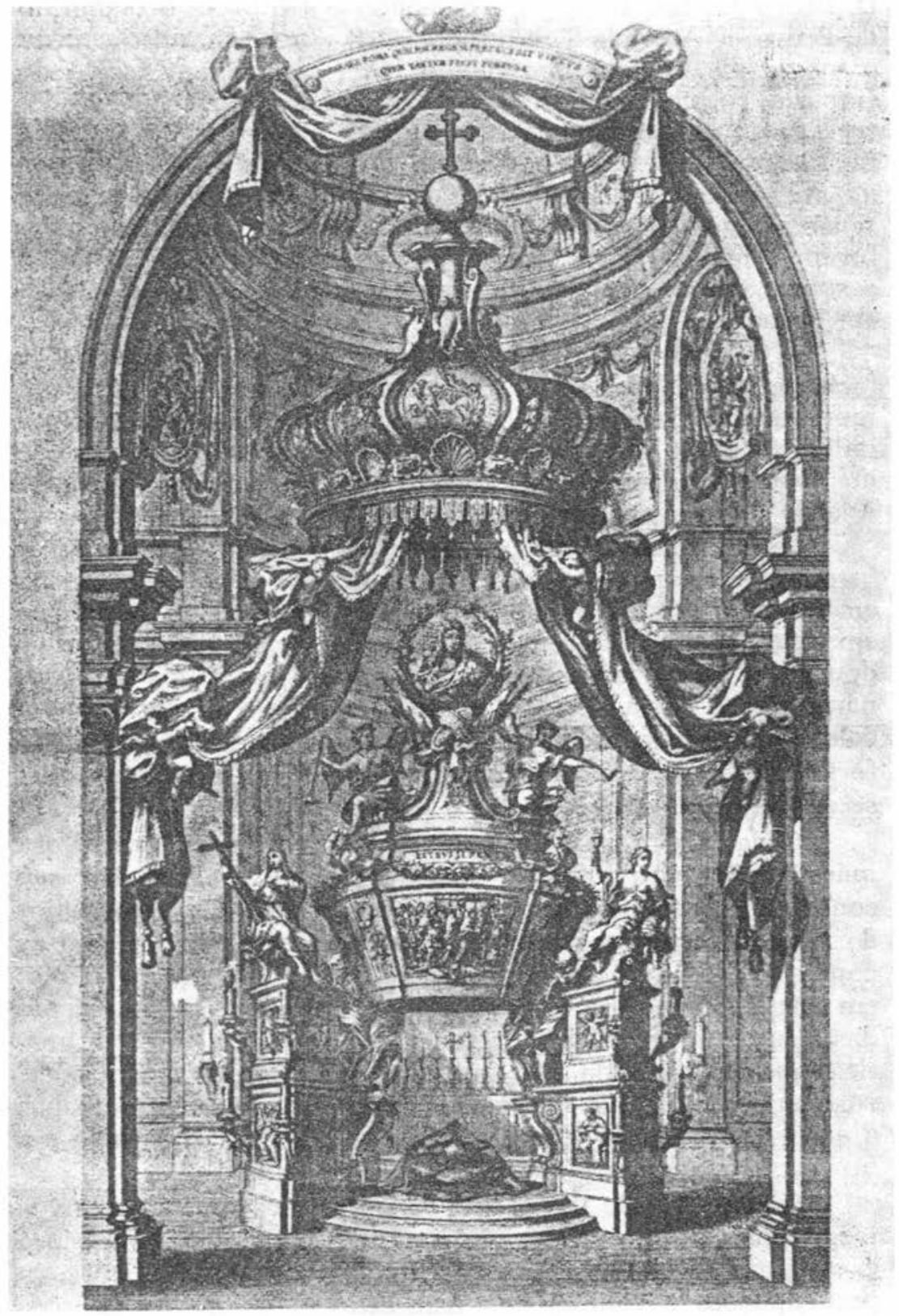

FIGURA 1 -Castrum Doloris de D. Pedro II na Igreja de Santo António dos Portugueses, em Roma. 
No quadro de uma mentalidade que se mantém estável, a novidade, digamos assim, consiste no efeito multiplicador do gesto e do ritual. Na celebração da vida, como na celebração da morte, a liturgia e a etiqueta, com o seu fixismo e rigidez, inundam todos os sistemas de representação.

Por isso, no trânsito do século XVII para o século XVIII, pelo menos à escala cortesã e aristocrática, a vertigem da morte instala-se dando lugar ao aumento do volume de práticas e discursos, num movimento de exaltação que apenas enfatiza o investimento necrófilo de uma sociedade marcada por um modelo de piedade genuinamente barroco.

A nobreza que confisca pela morte a memória da sua linhagem. e com ela dilata o seu património simbólico directamente ligado a acções heróicas e abnegadas, entrega-se, com maior afã, à consagração ritual da morte.

Naturalmente que o vínculo entre a morte e a família regulado pelo direito sucessório foi vivido e sentido pela nobreza. de uma forma peculiar, desde épocas recuadas. Não deixa no entanto de ser curioso notar que na altura em que, com mais aparato, se exterioriza o momento efémero do último adeus. surjam, de forma mais sistemática, as histórias da vida e proezas dos varões mais ilustres da monarquia.

No breve inventário que, em 1850, Figanière na Bibliographia Historica Portugueza apresenta dessas memórias elogios e epítomes, cerca de $70 \%$ dos títulos inscrevem-se entre 1690 e 1750 . Destes 86 títulos, 4 são publicados até 1720 e entre esta data e 1750 , concentram-se $90 \%$ daquelas obras, isto é, um total de 82 títulos.

Mesmo não considerando exaustiva aquela fonte, ela permite esboçar uma tendência inequívoca, a de que a nobreza, exaltando o presente, investe no conhecimento das suas origens e do seu passado $\left({ }^{15}\right)$.

(15) Para além da História Genealogica da Casa Real Portuguesa de D. António Caetano de Sousa, outras produções da Academia Real da História participam da finalidade de «Panteão Geral da Aristocracia Portuguesa», como já salientou Coimbra Martins, (artigo "Academias» in Dicionário de História de Portugal, dir. por Joel Serrão, Lisboa, Iniciativas Editoriais, 1975). No entanto, só uma história social atenta aos aspectos das representações culturais e mentais poderá analisar, no futuro, os estratos da nobreza representados neste moderno "panteão da aristocracia portuguesa" e indagar a leitura que a nobreza fazia de si própria. São inúmeros e compagiham largas centenas de páginas dos 15 volumes da Colleçam dos Documentos, Estatutos e Memorias da Academia Real da Historia Portugueza, os elogios fúnebres e epicédios memoriais alusivos a indivíduos e linhagens nobres. Mencionamos a título ilustrativo: José da Cunha Brochado, 
Obra maior neste domínio é a monumental Historia Genealogica da Casa Real Portugueza, desde a sua origem até o presente com as famílias illustres, que procedem dos Reys, $e$ dos Serenissimos Duques de Bragança, de D. António Caetano de Sousa (1735-1748) e ainda do mesmo autor, a significativa compilação das Memorias Historicas e Genealogicas dos Grandes de Portugal (1739).

Elogio de D. Fernando de Noronha, conde de Monsanto, tomo 3 da Coll. dos E. Doc. e Mem. Lisboa Occidental Officina de Paschoal da Silva, 1723. Idem, Elogio de D. Fernando Mascarenhas, Marquez da Fronteira, dos Conselhos de Estado e Guerra, Mordomo-Mor da Rainha, Presidente de Dezembargo do Paço, in Coll. dos E. Doc. e Mem., tomo 9, Lisboa Occidental, na Officina de José António da Silva, 1729; D. Pedro Miguel de Almeida Portugal, primeiro Marquez de Alorna. Elogio Funebre do Excelentíssimo Senhor Fernando Telles da Silva, Marquez do Alegrete, tomo 14 da Coll. dos E. Doc. e Mem., Lisboa Occidental, na Officina de José António da Silva, 1739; D. Francisco Xavier de Menezes, quarto Conde de Ericeira. Elogio de Francisco Dionisio de Almeida da Silva e Oliveira, Fidalgo da Casa Real, tomo 2 da Coll. dos E. Doc. e Mem., Lisboa Occidental, na Officina de Paschoal da Silva, 1722. A margem daquela monumental compilação, correram avulso muitos epítomes de vida e virtude de homens ilustres. Salientamos apenas alguns: Ultimas Acções do Duque D. Nuno Alvares Pereira de Mello...., relação do seu enterro, $e$ das exequias que se the fizeram em Lisboa, e nas terras em que era donatário...., Lisboa Occidental, na Officina da Música, 1730. Foi D. Manuel Caetano de Sousa quem recitou o seu Elogio Fúnebre, Lisboa Occidental, na Officina Joseph António da Sylva, Impressor da Academia Real, 1731. Sobre o primeiro Marquês do Cadaval publicaram-se, vários sermões e orações, como este por exemplo, Fr. Manuel de Figueyredo, Oraçam funebre nas Solenissimas exequias. Que no Convento da Graça de Lisboa Oriental celebrou a Nobilissima Irmandade dos Passos em 17 de Fevereyro de 1727 a seo Provedor o Excelentissimo Senhor D. Nuno Alvares Pereyra de Mello I Duque do Cadaval...., Lisboa Occidental, na Officina de Bernardo da Costa de Carvalho, 1727; na mesma linha, Julio de Mello de Castro, Historia Panegyrica da vida de Diniz de Mello de Castro, primeino conde das Galvêas, do Conselho de Estado e Guerra dos Serenissimos reis D. Pedro II e D. João V, Lisboa Occidental, na Officina de José Manescal, 1721 (esta obra teve pelo menos, 3 edições até 1752); D. José Barbosa, Epitome da vida do Illustrissimo e Excelentissimo Senhor, D. Luis Carlos Ignacio de Menezes, $1^{\circ}$ Marquês do Louriçal, quinto conde da Ericeira, do Conselho de Sua Magestade, duas vezes vice rei e capitam Geral do Estado da India, Lisboa, na Officina de Antonio Isidoro da Fonseca, 1743, do mesmo autor, Elogio do Senhor D. Francisco Xavier José de Menezes, $4 .^{\circ}$ Conde da Ericeira, Lisboa, na Officina de Ignacio Rodrigues, 1745. 
Eis, pois, um campo privilegiado para o desenvolvimento do cerimonial cortesão e, simultaneamente, para a afirmação pública do valor social e político da narração histórica $\left({ }^{16}\right)$.

\section{O culto dos mortos e a ritualização da História}

A mundividência subjacente àquelas narrações está, por seu turno, intimamente ligada à aguda consciência da violência e tirania do tempo, ou seja, à angústia do tempo que passa e é portador de morte, numa palavra, à profanização do tempo.

Mas na medida em que a morte permitia pelo rito e cerimonial reviver ou comemorar o momento primordial e simultaneamente histórico da sociedade cristã, ou seja, o mistério da paixão de Cristo, o tempo post mortem tornava-se para os vivos recordação e esperança na ressurreição. Sem levar muito longe esta valorização dinâmica de tempo, imanente ao próprio cristianismo, queremos apenas salientar que quanto mais intensa é a comemoração litúrgica da morte mais aguda se torna a consciência de salvar a tempo de uma vida, de transformar a sua recordação em história, e, consequentemente, em memória que se constrói age e evoca.

Nada mais adequado para exprimir esta sensibilidade do que a imagem do mundo como domicílio de luto que o teatro recria numa apelação do efémero e que a história ilusoriamente supera, perenizando a própria morte e ressuscitando, à dimensão terrena, o que jazia esquecido.

Rafael Bluteau expressa de forma paradigmática o sentido escatológico que presidiu à Academia Real da História considerando-a, desde logo, "Instituição de redenpção dos captivos" e explica: "captivos chamo todos aquelles Heroes Ecclesiasticos e Seculares, que desde muitos annos, e muitos seculos estão em muda tyrannia nas masmorras da esquecimento. Mayor cativeiro que este o não ha no Mundo; estar em prisão soterranea e não poder fallar nem ter hum postigo ou respiradouro por onde lançar hum sospiro. Ficar de baixo das ruínas dos antigos Mausoleos com epitaphios apagados em lapides carcomidas em si mesmas Sepultadas».

(16) Está por fazer, lamentavelmente, a História da Academia Real da História. Para além dos seus aspectos institucionais e do seu alcance cultural a Academia impõe uma ampla reflexão no âmbito da História da História. Cf. Joaquim Veríssimo Serrão, História Breve da Historiografia Portuguesa, Lisboa, Verbo, 1962, pp. 218-219; A. H. Oliveira Marques, Antologia da Historiografia Portuguesa, Lisboa, Publicações Europa-América, 1974. 
Nesta concepção em que a História prolonga e supera o túmulo e o epitáfio, a imagem do historiador é associada à do "Redemptor que com pia curiosidade vai desenterrando, e restituindo á luz do mundo vassalos dignos da lembrança e admiração da posteridade». Por isso Bluteau regozijado acrescenta: - "com as pennas dos nossos academicos se areanimarão as letras e se tornarão a afiar as espadas dos antigos portugueses, do mais profundo do rio Lethe virão a flor da agoa pessoas nos nossos annaes innonimadas; surgirão e ressurgirão boyantes sojeitos illustres miseravelmente somergidos» $\left({ }^{17}\right)$.

Aquela articulação que há pouco referíamos entre o teatro e a história e que marca, expressa ou indelevelmente, todas as manifestações da cultura e da mentalidade barrocas, encontra eco em outros textos da época $\left({ }^{18}\right)$.

Numa concepção cénica do mundo em que o homem é simultaneamente artifício e artífice, o tempo é sintoma de inquietação e veículo de verdade. Por isso, ele é figurado preso com cadeias de ferro no selo da Academia ou converte-se em passatempo obsessivo de D. João V que cultiva, com manifesta predilecção, uma enorme e riquíssima colecção de relógios.

Toda esta simbologia se precisa também na definição da História como «testemunho do tempo, luz da verdade, via da memória, mestre da vida e mensageira de Antiguidade» $\left({ }^{19}\right)$.

Mas a criação da Academia é também muito sugestivamente referida como edificação do "Templo da Memória». Dito de outro modo, de um espaço em que o culto do passado

(17) B.G.U.C. Cópia da Oraçam academica. Recitada em Palacio anno de 1721 pello P.e D. Raphael Bluteau, clério regular. Ms. 502, fl. $192-193 \mathrm{v}$.

(18) Ilustra-se por exemplo, neste passo: «Sendo o mundo theatro, em que para as mesmas scenas vay o tempo introduzindo novas figuras; se saberá haver melhor em qualquer negocio no noticioso dos sucessos passados, [que] discerne os presentes e prevê o futuro", Sebastião Pacheco Varela, Numero vocal, Exemplar, Catholico $e$ Politico, proposto no mayor entre os Santos o Glorioso S. Joam Baptista. Para imitaçam do mayor entre os Principes o Serenissimo $D$. João $V$. Nosso Senhor, Lisboa, na Officina de Manoel Lopes Ferreira, 1702 , p. 356.

(19) Manuel Teles da Silva, Historia da Academia Real da Historia Portugueza (por D...., Marquez do Alegrete, Secretario da mesma Academia) dedicada a El-Rey D. João V nosso Senhor, Lisboa Occidental, na Officina de Joseph Antonio da Sylva, Impressor da Academia, 1727, [p. 11]. 
impõe a celebração o que, no contexto da tradição judaico-cristã, remete para o desenvolvimento de uma memória litúrgica girando sobre si mesma (Le Goff) $\left({ }^{20}\right)$.

Paradigmaticamente, o culto que soleniza a abertura da Academia é o de Nossa Senhora da Conceição. A orientação é expressa por D. Manuel Caetano de Sousa: - «em o dia da Conceição se principiem a immortalizar, por meyo da Historia, as Igrejas Cathedraes de Portugal he agradecer-lhe a piedade com que todas ellas, seguindo a Metropolitana de Lisboa, jurarão no anno de 1646 a Conceição Immaculada, como tinha feito no mesmo anno o Senhor D. João IV» $\left({ }^{21}\right)$.

A criação da Academia Real da História ficava assim marcada por uma evocação simbólica e por uma recapitulação litúrgica - a Nossa Senhora da Conceição-que, celebrando as origens e respeitando a inspiração divina e providencial da monarquia portuguesa, se traduzia numa concepção que tendia a validar, segundo uma perspectiva cíclica, o segundo nascimento da monarquia portuguesa após a Restauração de 1640.

Logo, o espaço escolhido para as sessões da Academia era o mesmo em que "ha oitenta annos se fazião os congressos, em que quarenta fidalgos zelosos da liberdade Portugueza dispenserão se restituisse a coroa á serenissima Casa de Bragança» $\left.{ }^{(22}\right)$. Retorno a um topos ou lugar a que se confere dimensão religiosa no acto repetido da recapitulação do mistério de Nossa Senhora da Conceição. Por esta via se recobre de sacralidade o espaço profano do palácio real. A sua conversão em morada sacro-profana, em Palácio-Convento, tenha-se em vista a construção de Mafra - entronca, entre outros aspectos, neste acto de investidura simbólica.

Note-se, aliás, que a este culto de Nossa Senhora da Conceição tributou D. João V grande atenção desde o início do seu reinado. A 12 de Novembro de 1717, uma carta régia

(20) J. Le Goff, "Memória», in Enciclopédia Einaudi, 1-Me. mória - História, Lisboa, Imprensa Nacional-Casa da Moeda, 1984, Mircea Eliade, O Mito do eterno retorno...., H. Leclercq, "Memoria", in Dictionnaire d'archéologie chrétienne et de liturgie, vol. XI, tomo I, Letouze, et Ané, Paris, pp. 296-324; B. Gnenée, "Temps de l'histoire et temps de la mémoire au Moyen Âge", Bulletin de la Société de l'Histoire de France, n..$^{\circ}$ 487, pp. 25-36. Mémoires collectives: Actes du colloque, Bruxelles, Editions de l'Université de Bruxelles, 1984.

(21) Extracto da transcrição da célebre Proposicam da Academia da autoria de D. Manuel Caetano de Sousa, in Manuel Teles da Silva, ob. cit., p. 28 .

(22) Idem, ibidem, p. 29. 
expedida a todos os prelados das catedrais e colegiadas do reino manda que se observem nas celebrações do dia da Imaculada Conceição «as mayores demonstrações de grandeza e solenidade» $\left({ }^{23}\right)$. Para além do patrocínio, a Academia Real da História impôs, a cada um dos seus membros, o juramento da Imaculada Conceição, obrigação que já vigorava, há muito, na Universidade de Coimbra, que também, por provisão régia de 28 de Abril de 1720 , passa a conferir maior lustre e esplendor à sua festa e procissão $\left({ }^{24}\right)$. Este culto moderno da monarquia é objecto de derradeira prodigalidade régia em 1750 , com a oferta de uma imagem sagrada pelo papa Bento XIV à Basílica Patriarcal $\left.{ }^{25}\right)$.

O universo mágico-religioso que caracterizava a memória do monarca pode ainda divisar-se no seu apego ao momento heróico e mítico da fundação da monarquia. E ainda D. Manuel Caetano de Sousa que, ao justificar a primazia conferida à história eclesiástica do reino, o deixa entrever quando, ao «discorrer sobre os incrustaveis segredos de Providência", acrescenta que "a causa desta mysteriosa união da Historia Ecclesiastica que descreve a Santidade a fé e a piedade do nosso reyno e as vidas dos prelados que nelle plantarão, cultivarão e propagarão a fé, e que com a santidade de vida, a verdade da doutrina ensinarão a piedade, se mostra satisfeita na promessa de Christo ao Rey D. Affonso Henriques» $\left({ }^{26}\right)$. Ora esta visão aponta para o desenrolar de uma

(23) Fortunato de Almeida, História da Igreja em Portugal, vol. II, p. 258. Cf. Francisco Xavier da Sylva, Elogio Funebre, e Historico do Muito Alto, Podoroso. Augusto, Pio e Fidelissimo Rey de Portugal, e Senhor D. João V.... Lisboa, na Regia Officina Sylviana, e da Academia Real, 1750, pp. 49-50; Frei Claudio da Conceição, Gabinete Historico, vol. XII, Lisboa, Impressão Régia, 1827, pp. 273-274. Esta obra é no que concerne à reconstituição do reinado de $\mathrm{D}$. João $\mathrm{V}$, um perfeito decalque do Elogio Funebre de Francisco Xavier da Silva.

(24) Idem, ibidem.

(25) Como acrescenta Francisco Xavier da Silva, ob. cit., «He esta Imagem não só singular pelo, objecto, que representa, mas também estimavel pela preciosa prata dourada, em que se fabricou.... Deu Sua Magestade por este sagrado vulto cento e vinte mil cruzados: quantia, se consideravel quanto à materia, limitada para o affecto, com que desejava possuir semelhantes prendas, como dedicadas á Pureza da Virgem Maria Nossa Senhora, e sua singular Protectora», p. 51 .

(26) Manuel Teles da Silva, ob. cit., p. 30. Cf. Estatutos da Academia Real da Historia Portugueza, in ob. cit., pp. 45 e 46 . Sobre as mitologias de origem vide, Moses I. Finley, "La Constitution des Ancêtres», in Mythe, Mémoire et Histoire, Paris, Flammarion, 1981, pp. 209-251; Sobre os mitos em geral salientamos, Walter Burkert, Mito e 
epopeia mística e piedosa a partir de um acontecimento fundador marcado pela intervenção divina. No sentido em que a história era percebida como desenvolvimento e ilustração desse momento primordial de revelação cristológica tornava-se teofania.

Esta concepção projecta-se com maior evidência no longo e demorado processo de colacção de provas do milagre de Ourique tendentes a habilitar o processo de canonização de D. Afonso Henriques, instruído primitivamente em 1556 por iniciativa dos cónegos de Santa Cruz, com a protecção de D. João III, e retomado após a Restauração e nos reinados de D. João V e D. José I.

São no entanto anteriores os primeiros documentos que referem a lenda de Ourique. Datam dos inícios de quatrocentos, do século da dinastia de Aviz. Como salienta José Mattoso, "não admira que, na época em que a consciência nacional se torna mais nítida, a partir da luta pela independência, em 1385 , se tenha escolhido este acontecimento, e não São Mamede, como símbolo da nacionalidade. Com efeito, ele era muito mais adequado para fazer intervir a sobrenatural, porque punha em jogo a luta entre a Cristandade e o Islão, e para fazer revestir o rei de uma missão Sagrada.... Ourique fica, portanto, desde o século de Aviz, a constituir o ponto de partida da nação, e perante os historiadores da época e do século seguinte, deixa S. Mamede na obscuridade» $\left({ }^{27}\right)$.

Acrescente-se, que este processo de transformaçãa da imagem do rei em figura mítica e sacralizada é também contemporânea dos grandes embates civilizacionais provocados pela expansão marítima. Impondo um sentimento de identidade e filiação, a imagem do rei, forjada como matriz da memória do reino, entronca numa linha de valorização do passado que cria filiação e missão de grandeza. A sua construção, porém, recria-se num imaginário popular que hiper-

Mitologia (tradução de Maria Helena da Rocha Pereira), Coimbra, Faculdade de Letras, 1986; Mircea Eliade, ob. cit., Marcel Detienne, "Mito/Ritow in Enciclopedia Einaudi, 12, Lisboa, Imprensa Nacional-Casa da Moeda pp. 58-74, G. P. Caprettini e outros, "Mythos/Logos», ibidem, pp. 75-104. A memória colectiva sendo ahistórica está, por vezes, intimamente relacionada com as representações mágicas e míticas das origens das sociedades e dos povos. A este respeito vide, Pierre Nora, "Mémoire Collective», in Nouvelle Histoire (dir. de J. Le Goff, Roger Chartier e J. Revel), Paris, Retz. 1979, pp. 398-401, e M. Halbwanchs, Mémoires collectives, Paris, P.U.F., 1950.

(27) José Mattoso, "A primeira tarde portuguesa», in Portugal Medieval. Novas interpretações, Lisboa, 1985, pp. 13-14. 
boliza o insondável, o desconhecido e o milagre e que aproxima a vida e a figura do santo do quotidiano.

Embora tendo um fundo estável a mensagem de Ourique foi sendo objecto de apropriações sucessivas e nem sempre absolutamente idênticas. Ora, quando se erige a possibilidade de elaboração de uma História nacional, no âmbito da Academia, Ourique configura um acontecimento primordial cujo desenvolvimento ficava assinalado pela promessa imperial $\left({ }^{28}\right)$.

Para avaliar da importância atribuída a este acontecimento refira-se que a Cronica de d'El Rei D. Affonso Henriques, escrita por Duarte Galvão em 1505, foi pela primeira vez impressa, em 1726. A edição saíu expurgada dos capítulos XXI, XXII, XXIII e XXIV, isto é, dos episódios que denegriam a figura idealizada e piedosa do rei $\left({ }^{29}\right)$. Na Academia

${ }^{(28)}$ Por ordem cronológica são as seguintes as primeiras narrativas conhecidas da lenda de Ourique: De ministerio Armorum (1416); A Crónica dos sete primeiros reis de Portugal, também chamada Crónica de 1419; a Segunda Crónica Breve de Santa Cruz de Coimbra (1451); a Oração de obediência de Vasco Fernandes de Lucena (1485) e a Cronica d'El-Rei D. Affonso Henriques de Duarte Galvão (1505). Sobre a fixação literária da lenda de Ourique continua a ser imprescindível o recurso a L. F. Lindley Cintra, «Sobre a Formação e Evolução da lenda de Ourique (Até à Crónica de 1419)», Revista da Faculdade de Letras de Lisboa, tomo XXIII, III Série, n. ${ }^{1}$, Lisboa, 1957, pp. 168-215; Vejam-se também os contributos de Aires Augusto Nascimento, "O milagre de Ourique num texto latino-medieval de 1416», Revista da Faculdade de Letras de Lisboa, IV Série, n. ${ }^{\circ}$ 2, 1978, pp. 365-374; António de Vasconcelos, "O escudo nacional português (Lenda e História)», Lusitania, Revista de Estudos Portugueses, vol. 1, fasc. II, Março de 1924, pp. 171-185, fasc. III, Junho de 1924, pp. 321-337. O processo de beatificação de D. Afonso Henriques é particularmente tratado e documentado por Idalino Ferreira da Costa, «Tentativas de Canonização de el-Rei D. Afonso Henriques", Anais da Academia Portuguesa de História, II Série, vol. VIII, Lisboa, 1958; em Joaquim Martins de Carvalho, Algumas horas na minha livraria, Coimbra, Imprensa Académica, 1910, encontramos a pp. 262-263 a seguinte referência: "No primeiro de dois volumes manuscritos que possuímos, relativos aos mosteiros de S. Marcos, de Belém, e do Mato...., encontra-se uma curiosíssima Dissertação sobre a canonização de 'D Affonso Henriques, cópia de um manuscrito antigo». O estado da questão e a apresentação de bibliografia mais exaustiva é feita por Ana Isabel Carvalhão Buescu, O Milagre de Ourique e a História de Portugal de Alexandre Herculano. Uma Polémica oitocentista, Lisboa, Instituto Nacional de Investigação Científica, 1987.

(29) A este respeito é particularmente elucidativa a licença do censor régio e membro da Academia Real da História, o teatino, D. José Barbosa, in Duarte Galvão, ob. cit., pp. 38-39, cit. in Ana Isabel Carvalhão Buescu, ob. cit., p. 131 
Real da História é confiada a D. João de Santa Maria de Jesus a compilação dos documentos existentes e a busca de novas fontes. Com idêntico objectivo o tomo V (parte 1) das Provas de Historia Genealogica insere o fragmento do testamento, ou codicilo del Rey D. Affonso I, pretensa cópia de um pergaminho do cartório do cabido de Viseu.

Em Roma publica-se, em 1728, de autoria de José Pinto Pereira, o Apparatus Historicus de Argumentis Sanctitatis Regis Alphonsi Henriques, dirigido ao Santo Padre Bento III. No sentido de dar maior divulgação a uma das peças mais importantes do processo de beatificação reeditam-se, em 1749, os Dialogos de varia historia em que se referem as vidas dos Senhores Reys de Portugal, com os seus mais verdadeiros retratos: e noticias de novos Reynos e conquistas $e$ varios successos do Mundo, de Pedro Mariz. A obra incluía o auto de juramento de Afonso Henriques cuja primeira versão, datada de 1559, constava da 2 . $^{\text {a }}$ edição do texto de Mariz, ou seja, saíra publicada antes da sua fixação definitiva pelo alcobacense Frei Bernardo de Brito na Crónica de Cister, de 1602.

Durante o século XVIII o aspecto mais singular e curioso da argumentação expendida em favor da beatificação do rei consiste na atribuição a S. Bernardo da profecia de Ourique. Encontravam os teólogos e canonistas - com excepção e oposição até dos jesuítas - na leitura dos sermões do santo sobre a paixão de Cristo, referências directas à aparição de Ourique.

Em abono de tão insistente causa, Roma concedia, em 1733 , ao clero português, o ofício e missa das cinco chagas, à semelhança, aliás, do que havia aprovado para os regulares de Santa Maria dos Anjos de Florença $\left({ }^{30}\right)$. Mas a expectativa em torno da bula de beatificação tornava a crescer na década de quarenta com a publicação da bula da canonização da rainha Santa Isabel (1742) $\left.{ }^{\left({ }^{31}\right.}\right)$. Sendo causa conjunta da Igreja e do Estado, este processo arrastar-se-á pela segunda metade do século XVIII, encontrando eco em dois homens de

(30) Francisco Xavier da Silva, ob. cit., pp. 283-285.

(31) A bula de canonização da rainha Santa Isabel de Bento XIV, datada de 28 de Abril de 1742, é transcrita por António de Vasconcelos, A Evolução do Culto de dona Isabel de Aragão, Coimbra, Imprensa da Universidade, 1894, pp. 309-332. 
vasta cultura e saber teológico, António Pereira de Figueiredo e Frei Manuel do Cenáculo $\left({ }^{32}\right)$.

$\mathrm{O}$ ponto culminante desta campanha, digamos mesmo, a maior concessão feita à igreja portuguesa por Roma consistia na aprovação, requerida pelo patriarca $\mathrm{D}$. Tomás de Almeida a Bento XIV, de uma longa referência ao milagre de Ourique na celebração da $6 .^{\mathrm{a}}$ lição do ofício das chagas $\left({ }^{33}\right)$.

(32) Sobre a matéria escreveu António Pereira de Figueiredo, Dissertação historica e critica, em que se prova a milagrosa apparição de Christo Senhor Nosso a El Rei D. Affonso Henriques antes da famosa Batalha do Campo de Ourique, Lisboa na Officina de Simão Thadeo Ferreira, 1786; idem, Elogia rerum lusitanarum: Latine et Lusitane historicis et criticis notis ilustra. Elogios dos Reis de Portugal...., Lisboa, na Officina de Simão Thadeo Ferreira, 1785; idem, Novos Testemunhos da milagrosa apparição de Christo Senhor Nosso a El-Rei D. Affonso Henriques antes da famosa Batalha do Campo d'Ourique: e exemplos parallelos, que nos induzão á pia crença de tão portentoso caso, Lisboa, Regia Officina Typografica, 1786. Embora não abordando este aspecto do pensamento do Pereira de Figueiredo, é de grande interesse o recente estudo de Zília Osório de Castro, "O Regalismo em Portugal. António Pereira de Figueiredo", Cultura, História e Filosofia, vol. VI, 1987; vide de Frei Manuel do Cenáculo, Cuidados literários do Prelado de Beja em Graça do seu Bispado, Lisboa, na Officina de Simão Thadeo Ferreira, 1791; e Graças concedidas por Christo no Campo de Ourique, acontecidos em outros tempos e repetidas no actual, conforme aos desenhos de suas idades, Lisboa, na Impressão Regia, 1813. Sobre Frei Manuel do Cenáculo continua a ser indispensável o recurso a Francisco Gama Caeiro, Frei Manuel do Cenáculo. Aspectos da sua actuação filosófica, Lisboa, s. 1, 1959. A par daqueles autores setecentistas, outros, menos conhecidos, escreveram em abono do milagre de Ourique, reforçando consequentemente a corrente de opinião favorável à beatificação de Afonso Henriques, vide por exemplo, Dionisio Teixeira de Aguiar, Relaçam verdadeira da Appariçam de Christo Senhor Nosso, no Campo de Ourique, ao Santo Rey Dom Affonso Henriques...., Lisboa, s. e, 1753.

(33) E o seguinte o texto do decreto que fez a concessão do ofício para Portugal, em 1753: «Decreto do Reino de Portugal, e dos Algarves. Para satisfazer á grande Devoção, que nos Reinos, Domínios e Conquistas de D. José I Rei Fidelissimo de Portugal, e dos Algarves, está no maior vigor para com as Sacrantissimas Chagas de Nosso Senhor Jesus Christo. Se supplicou por parte do Emminentissimo e Reverendissimo Cardeal D. Thomaz Patriarcha de Lisboa ao Santissimo Papa Benedicto XIV Nosso Senhor, se dignasse extender ao Clero Secular, e Regular do Rei Fidelissimo a graça de celebrar na primeira Sesta Feira, depois de Cinza, o officio proprio com Missa das cinco Chagas do mesmo Nosso Senhor Jesus Christo, já approvado no dia quatro de Julho de 1733, para as Regulares de Santa Maria dos Anjos da Cidade de Florença; com aditamento no fim da sexta lição das palavras abaixo escriptas. A saber:

As quaes milagrosamente recebeo para suas Reaes Armas o Imperio Lusitano. Por quanto se refere: que apparecendo Nosso 
Confina-se, assim, o milagre a uma evocação meramente ritual e litúrgica mas em todo o caso de larga repercussão na piedade popular e na mentalidade colectiva. A importância atribuída à "Sciencia das Cerimónias" ${ }^{34}$ ) no reinado de D. João $\mathrm{V}$ justifica a inclusão, mesmo à posteriori, daquela referência na liturgia das chagas.

No essencial, o rito que recapitulava a memória da paixão de Cristo e trazia implícita a origem do tempo cristão tornara-se pretexto para a comemoração de um outro nascimento, o da pátria portuguesa. Sinal de uma investidura simbólica,

Senhor Jesus Christo Crucificado a Affonso I no Campo de Ourique, quando estava para entrar em batalha com os sincos Reis arabes: e promettendo-lhe a victoria inesperada; lhe ordenou compozesse o Escudo das suas Reaes Armas do preço porque havia remido o genero humano. Donde começou a ter princípio a particular Devoção das Santissimas Chagas de Christo em todo o Imperio Luzitano. E Sua Santidade tendo ouvido o Reverendo Padre Luiz de Valentibus Promotor da Fé, concedeo benignamente, que daqui em diante nos referidos Reinos, Dominios, e Conquistas do mesmo Fidelissimo Rei se possa recitar, e respectivamente celebrar o pertendido Officio com Rito de Duplex maior, com Missa, e acrescentamento, que assima fica escripto. Dia 15 de Dezembro de 1753», cit. in Quintanario Meditativo, e Fervorosa supplica em louvor das sinco Chagas de nosso Senhor Jesus Christo. Offerecido ao mesmo Senhor, e por Elle dadas, para Brazoens do seu imperio, ao Real Tronco Luzitano; o Senhor D. Affonso Primeiro. Dedicado ao Senhor D. João, Principe do Brazil. A Igreja Santa approvou, e concedeo esta devoção por huma Bulla Apostolica, e nella se vê a verdade de sua origem. Por Dionizio António de Paiva, Lisboa, 1797.

( $\left.{ }^{34}\right)$ A expressão é retirada de Francisco Xavier da Silva, ob. cit., p. 68. A importância atribuída por D. João $\mathrm{V}$ ao cerimonial litúrgico documenta-se nos trabalhos que encomendou a Jose Assemano e Estevão Evadio Assemano relativos aos ritos Grego, Arménio, Siríaco, Maronita, Jacobita e outros. Assim, por ordem do monarca, Estevão Evodio Assemano imprimiu em Florença, em 1742, a monumental Bibliothecae Medicae Laurentianae, \& Palatinae Codd. M.M.S. Orientalium Catalogus notis illustratus. Na mesma linha de valorização formal se enquadra, embora no âmbito do cerimonial laico e profano, a regulamentação introduzida por alvará de 29 de Janeiro de 1739, das formas de tratamento nominais. Sobre este tema vide L. F. Lindley Cintra, Evolução das formas de tratamento em Português, Lisboa, 1967. Culminando um virtuosismo de estilo que sintetiza exemplarmente uma sensibilidade barroca, D. João V impôs ao exercício do poder uma cenografia faustosa e aparatosa, conforme o documenta Rui Bebiano, ob. cit. Veja-se também, Yves Bottineau, "Le goût de Jean V: Art et Gouvernement", Bracara Augusta, vol. XXVII, n. 64 (76), Braga, 1973, pp. $341-353$ e Luis Vasco Ribeiro Salgado de Oliveira «O significado do Luxo no Reinado de D. João V. Alguns aspectos», Bracara Augusta, vol. XXVII, n. ${ }^{\circ} 64$ (76), Braga, 1973, pp. 299-312. 
as chagas de Cristo, tomadas desta forma como objecto de culto, permitiam uma transposição cerimonial curiosa, inserindo a vivência ritualizada do mito fundador na vida social.

Passando do espaço sagrado para o espaço profano, isto é, do lugar ocupado pela liturgia para a mise en scène do imaginário social que era o espectáculo das entradas régias, verifica-se que no tempo de $\mathrm{D}$. João $\mathrm{V}$, o recurso à gestualidade da veneração da cruz de Cristo, impunha o mesmo sentimento de retorno a esse momento de iniciação de raíz cristológica. Como dizia um contemporâneo, "os actos desta veneração, por serem repetidos, se fazem inumeráveis, e até luzirão nas occasiões em que [o rei] fez algumas entradas publicas» $\left.{ }^{35}\right)$.

Daqui decorre também o sentido último das sucessivas regulamentações prescritas para o mais importante desfile religioso de Lisboa, a Procissão do Corpus Christi. A de 1719. e depois dela todas as outras, baniu todas as sobrevivências profanas e pagãs da festa. A partir de então fazia-se derivar com enorme visibilidade e espectacularidade toda a sociedade, minuciosamente representada e rigorosamente hierarquizada, da figuração das chagas de Cristo, naquilo que podia talvez ser a imagem que a própria sociedade oferecia de si mesma.

\section{Mecenato escatológico e piedade barroca}

Para além deste significado mais profundo e escondido retenha-se que, na piedade barroca, o lenho da cruz materializava sempre o sentido da meditação da morte. Peça essencial no exercício da boa morte, a sua evocação era constante na pastoral tridentina e a sua referência obrigatória nos testamentos. O tema da Paixão era por excelência, numa "religião de recordação" como o cristianismo, memória paradigmática da morte e abertura ao culto dos mortos $\left({ }^{36}\right)$.

Aqui se estabelece uma linha de correspondência curiosa. De facto, o desenvolvimento da memória dos mortos e dos santos atingiu grande relevância no reinado de D. João V. São disso exemplo as aparatosas consagrações dos mortos memoráveis, dos mártires e santos em sucessivas festas de canoni-

(35) Francisco Xavier da Silva, ob. cit., p. 47.

${ }^{\left({ }^{6}\right)}$ Michel Vovelle, ob. cit., pp. 290-302; Philippe Ariés, O Homem Perante a Morte I, Lisboa, Publicações Europa-América, pp. 232 -237 . 
zação realizadas, dias a fio, em Lisboa como em todo o país, todas elas patrocinadas e estipendiadas pelo monarca. Armaram-se igrejas e fizeram-se oitavários, por exemplo por S. Toribio Morovejo, S. Peregrino Laziozi (1727), S. Luiz Gonzaga, S. Stanislao Koska (1727), S. João da Cruz (1727), S. João Nepomoceno (1730), S. Francisco Régis (1737), S. Vicente de Paulo (1738) e S. Camilo de Lellis (1747) $\left(^{(37}\right)$.

Também o culto dessas entidades simbólicas que materializavam o sagrado, ou seja, o culto das relíquias, foi erigido em montra de santidade pelo rei. Assim, e porque se atribuía um valor mágico à memória dos mortos beatificados. D. João V manda erigir em 26 de Novembro de 1744, um "especialissimo Santuário de relíquias em uma das capelas da Igreja Patriarcal», fazendo publicar o respectivo catálogo. Segundo um contemporâneo era todavia, «incomparavelmente mayor a colecção que se conservava no Palácio Régio" ${ }^{38}$ )

Deixava ainda o rei o seu nome ligado ao panteão dos mortos exemplares mandando imprimir, a expensas suas, em Roma no ano de 1748, uma edição luxuosa do Martyrologio Romano $\left({ }^{39}\right)$.

Independentemente das motivações do rei, a mesma intensidade devocional parece caracterizar a mentalidade colectiva. Pois sendo "os Reys espelho dos vassalos» eram muitos os que "tomando o exemplo na devoção de Sua Magestade.... ordenarão também instituicões (pias)" - e concretizava o mesmo autor - "a evidência qualificará esta verdade se entrarmos nos templos de Nossa Senhora dos Anios, de Nossa Senhora dos Martyres de Nossa Senhora da Conceição, dos Santos Martyres de Lisboa e da Real Casa de Santo António.... além de outros tantos na paroquial de S. Nicolau.... acharão alguns instituidores estímulos nara empregarem os cabedais aue possuhião em cousa de tanto agrado a Deus e utilidade das bemditas almas do purgatório» $\left({ }^{40}\right)$.

${ }^{\left({ }^{3}\right)}$ Encontra-se uma vastíssima colecção de sermões de canonização desta época, em vários volumes de miscelâneas da B.G.U.C.. Foram-nos particularmente úteis os volumes, 164 a 167,310 e 323.

(38) Francisco Xavier da Silva, ob. cit., p. 62.

(39) Idem, ibidem, p. 63. O devocionário dos santos está intimamente relacionado com o culto das relíquias. De facto em 1744 o ilustre académico António Caetano de Sousa dava continuidade à obra de Jorge Cardoso, Agiologio Lusitano dos Sanctos e varões illustres em virtude do reino de Portugal e suas conquistas. É assim da sua autoria o t. IV desta obra, publicada na Régia Officina Silviana em 1744.

(40) Francisco Xavier da Silva, ob. cit., pp. 94 e 95. 
Com o fim de aplacar a justiça divina e preparar a salvação dos seus vassalos obteve D. João V do papa Bento XIV inúmeras indulgências, entre as quais a mais importante terá sido o chamado Jubileu das Quarenta Horas. Como observava um contemporâneo - "Não se contentava o monarca que a sua piedade fosse tão útil aos homens no estreito campo da vida; porque também solicitou estendella até essas vastas regiões da morte» $\left({ }^{41}\right)$.

Para a mentalidade da época era "máxima de grande político acrescentar mais a Deos a corte do Impíreo com as almas que resgatava do fogo do Purgatório" $\left({ }^{42}\right)$. Daí a sua súplica ao papa Bento XIV para que todos os sacerdotes regulares e seculares pudessem rezar, em vez de uma, três missas no dia de fiéis defuntos. Assim, neste dia de memorial, que por influência de Cluny se impôs no calendário cristão desde o séc. XI, se recapitulava de forma mais insistente a licão que os lug̣ares escatológicos da memória católica - o Paraíso, o Inferno e o Purgatório - encerravam.

Paralelamente, várias fontes referem a conta corrente aberta pelo rei para missas pelas almas do Purgatório. Uns autores calculam que dispendia todos os anos, 5,6 ou $8 \mathrm{mil}$ cruzados de missas $\left({ }^{43}\right)$. Outros referem que só nos últimos anos do seu reinado mandou rezar mais de 700000 missas a 240 réis cada uma o que equivale a um gasto de 350000 cruzados $\left({ }^{44}\right)$.

Segundo Diogo Barbosa Machado, «Desde os primeiros annos do seu governo luzira no seu espírito huma ardente devoção de libertar do Purgatório as almas", de tal forma que "parecerá incrivel a despeza e o afecto com que mandava celebrar missas em todas as igrejas para seu benefício, excedendo milhões o gasto que faz em tão santa obra....» ( $\left.{ }^{45}\right)$.

Não admira, pois, que um viajante francês registasse com tanta ironia esta obsessão do monarca português: "Ocultavam-lhe [ao rei] cuidadosamente as pessoas que morriam em Lisboa, porque mal soubesse que um dos seus subditos tinha

(41) Teodoro de S. José, Oração Funebre nas Exequias del Rei D. João $V$ de Portugal, Lisboa, na Officina dos herdeiros de António Pedrozo Galram, 1751, p. 26.

(42) Idem, ibidem.

(43) Idem, p. 27.

(44) Francisco Xavier da Silva, ob. cit., pp. 67-68.

(45) Diogo Barbosa Machado, Relaçam da Enfermidade, ultimas Acçoens, Morte, e Sepultura do Muito Alto, e Poderoso Rey, e Senhor D. João V...., Lisboa, na Officina Ignacio Rodrigues, 1750, p. 17. 
morrido, mesmo que fosse um homem do povo, logo mandava, á sua custa, rezar-lhe pelo menos 100 missas. Os portugueses diziam que João enviava os vivos para o inferno para tirar os mortos do purgatório» $\left({ }^{46}\right)$.

Como se vê, a vertigem da morte acabava por ser aplacada por uma inflação de gestos que atingia o absurdo. A mundividência que reflecte esta carga piedosa e exuberância de atitudes é tipicamente barroca na sua intencionalidade e materialidade.

A singularidade deste zelo escatológico radica na subversão que, à escala da monarquia absoluta, instalava na própria concepção de soberania. De facto, D. João $\mathrm{V}$ não só reinava sobre todos os seus súbditos vivos como estendia a sua soberania aos súbditos defuntos. Assim. segundo outro autor, "o rei com uma tocha na mão chegou a acompanhar os religiosos defuntos á sepultura». gesto que, comentava, «em nenhum monarca jamais se vio, por ser acção na opinião do mundo e uso das cortes contra a Razão de Estado da Monarquia» $\left({ }^{47}\right)$. Atente-se que o comentário fixa o gesto em si e o que ele prolonga em termos de subordinação do poder temporal ao espiritual.

Mas o mecenato escatológico do monarca estende-se ainda a outros campos. Revela-se no avultado número de livros de devoção e preparação da morte cujas despesas de impressão corriam a cargo do erário. Este aspecto, associado à protecção que a seita sigilista gozava na corte joanina, poderá explicar a evolução do movimento editorial das ars moriendi, manuais de preparação da morte, e exercícios espirituais em Portugal. Levantamento por nós realizado e que permite verificar um crescimento constante de primeiras edições até 1720 e uma subida em flecha no segundo quartel do século.

Entre várias obras saídas a lume pela primeira vez no século XVIII e que registaram várias edições até meados do século, está uma que consideramos ser uma das mais lidas neste período. Trata-se do Mestre da vida, que ensina a viver e morrer Santamente, de Frei João Franco (1731) e que em 1762 ia já na sua $20 .^{2}$ edição, sem contar com as contrafacções

(48) G. Dumouriez, État présent du Royaume de Portugal, en l'année MDCCLXVI, Lausanne, François Grasset, 1775, p. 250.

${ }^{(47)}$ Fr. Joseph de N. S. do Pilar, Epicedio panegyrico nos solemnes exequias Do nosso Augustissimo e sempre memoravel Rey e Senhor D. João V...., Lisboa, na nova Officina de Manoel Coelho Amado, 1751, pp. 23-24. 
a que deu azo, superando, assim, a fama e o prestígio do setecentista P. ${ }^{\cdot}$ Estevam de Castro com o seu Breve Aparelho, e Modo facil para ajudar a bem morrer hum christão, cuja primeira edição é de 1621 e que ainda se reeditava em finais do século XVIII.

Um outro título, Lembrança da Senhora da Boa Morte para bem morrer, publicado em Lisboa em 1730, por António Pedroso Galrão, precede a criação da Congregação do Senhor Jesus da Boa Morte e Caridade que teve como fundadores em 1736, os monges das covas de Montemor. No mesmo ano instalava-se na capital onde alcançou grande influência. Outras duas congregações, orientadas para a penitência e preparação da morte, colheram a protecção do monarca, a dos Agonizantes, na Igreja dos Jesuítas de S. Roque e a congregação da Missão dos padres Lazaristas.

\section{Homologias: messiânica e martirológica}

Para além do paradigma de monarca piedoso, irmão da confraria do Santíssimo Sacramento, penitente da ordem terceira de S. Francisco, cujo hábito usará como mortalha com o bentinho de Nossa Senhora do Carmo ao peito réplica fiel, afinal, do testador piedoso da primeira metade do século - permanece, como traço singular, a imagem do rei iluminado investido de uma missão profética e messiânica. à escala do mundo e do império. Como dizia um autor, o rei assemelhava-se a "um Arquimedes político» que lançava do centro, da corte, "linhas imaginárias a todos os pontos do orbe, especulando no triângulo do tempo, a glória do passado o perigo do presente e a segurança do futuro" $\left({ }^{48}\right)$.

No imaginário régio, o estigma sagrado das origens do reino reforçava a expectativa escatológica do Quinto Império. Nesta perspectiva, o orbe inteiro, unido pelo destino português, renderia obediência à cidade mais próxima de Deus e eleita como última capital do império do mundo, Lisboa.

A primeira manifestação desta mundividência imperial de inspiração messiânica e sebastianista surge na História da Congregação de S. João Evangelista, escrita em 1697, por

(48) Teodoro de S. José, ob. cit., p. 24. Sobre as manifestações piedosas dos testadores da época, vide especialmente, João Lourenço Roque, Atitudes Perante a Morte na Região de Coimbra. De meados do Sec. XVIII a meados do Sec. XIX. Notas para uma investigação. Coimbra, 1982. 
Francisco de Santa Maria, O Ceo Aberto na Terra, cuja gravura e prólogo, dedicado ao príncipe. revestem grande importância para a nossa análise (figura 2).

No texto de abertura, o futuro rei D. João V é, desde logo, antevisto com a "coroa e o diadema do quinto e Universal Império» que, como se acrescenta, "Deus prometeu estabelecer nos descendentes do primeiro Rey D. Affonso, a quem deu como penhor da mesma promessa, e com grande proporção a este número as cinco chagas por armas» $\left({ }^{49}\right)$. A imagem que substancia estas palavras é ainda mais complexa e sugestiva. A cena principal desenrola-se ladeada por cuas colunas que figuram nomes insignes da congregação, sendo uma delas encimada por S. Jorge e outra por S. João Evangelista. As imagens centrais organizam-se verticalmente. Ao cimo, o céu aberto do apocalipse de $\mathrm{S}$. João que prenuncia, numa imagem de esplendor, a chegada «do fiel e verdadeiro que julga e faz a guerra com justiça» (Apoc. 19.II). No ponto mais alto do céu um raio de luz irradia de Deus, atravessando um arco triunfal em direcção às cinco chagas de Cristo gravadas no escudo português, à esquerda. E o iovem príncipe, figurado ao centro, sentado sobre um dossel de um trono. ladeado por dois leões e envergando um ceptro na mão esquerda, quem acolhe numa atitude expectante e de elevação espiritual a luz divina que. à sua frente, o escudo refracta. $\mathrm{Na}$ linha do horizonte, ao fundo, o sol desponta com um brilho e uma luz insignificante, em relação à que emana do céu.

Esta expectativa messiânica documenta-se igualmente em outra obra escrita poucos anos depois, em 1702, Número Vocal, Exemplar Catholico e Político, de Sebastião Pacheco Varella e igualmente dedicada ao príncipe. Trata-se de um texto singular, com anotações musicais impressas à margem, ordenado e dividido segundo preceitos, talvez cabalísticos, e em que se enunciam sistematicamente as virtudes e a sabedoria que o futuro rei deveria possuir e cultivar. Num exercício de ostentação visual, a formação do rei, preocupação central da obra, desenrola-se num cenário imaginário

(49) Francisco de Santa Maria, O Ceo Aberto na terra. Historia das Sagradas Congregações dos Conegos Seculares de S. Jorge em Alga de Veneza e a S. João Evangelista em Portugal...., Lisboa, na Officina de Manoel Lopes Ferreyra, 1697, p. 3. Sobre a estampa que acompanha esta obra, vide Ernesto Soares e Henrique de Campos Ferreira Lima, Dicionário de Iconografia Portuguesa, 2. vol., Lisboa, Instituto para a Alta Cultura, 1948, p. 206. 


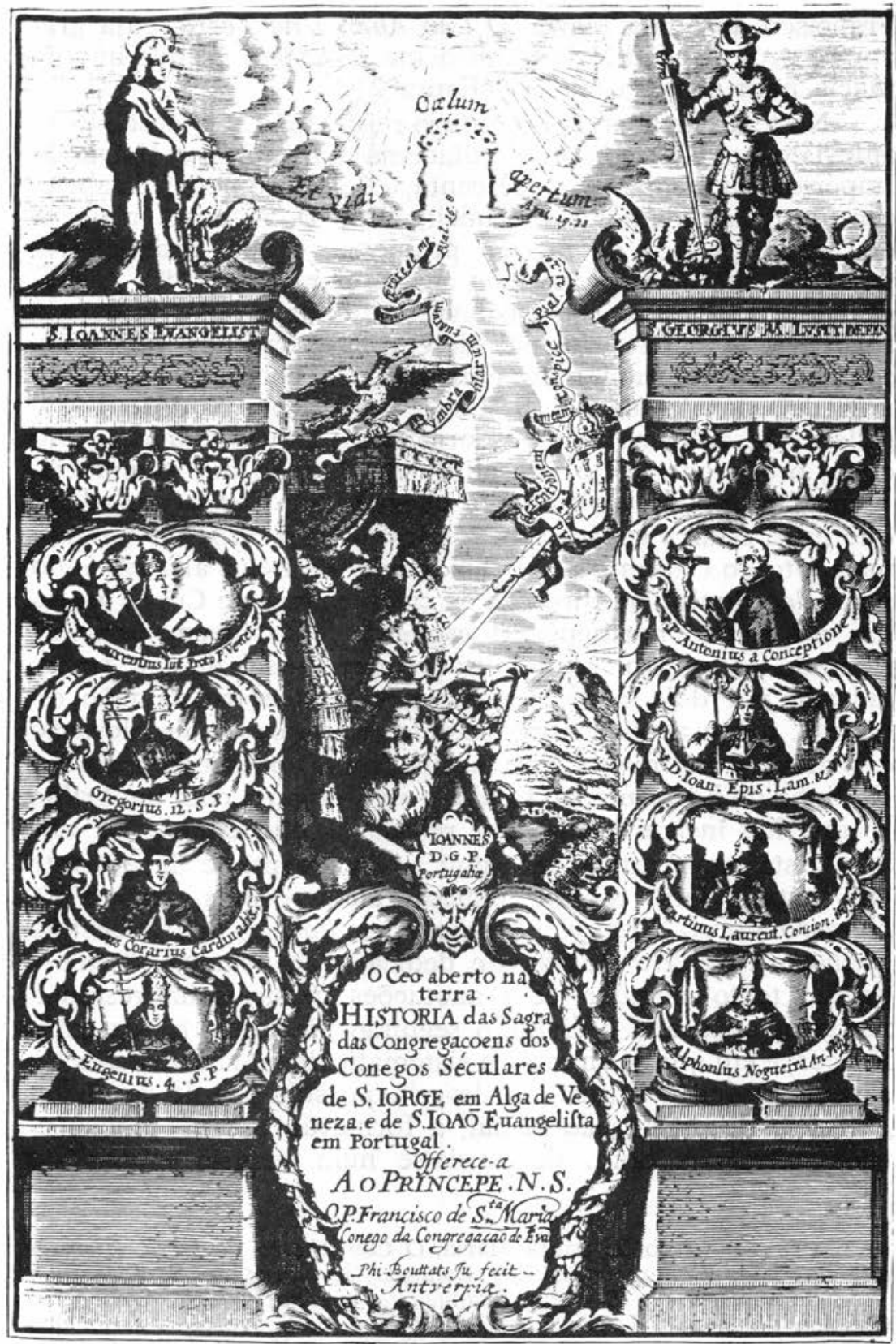

FIGURA 2-Figuração do Príncipe e futuro rei $D$. João $V$. 
Morte, memória e piedade barroca

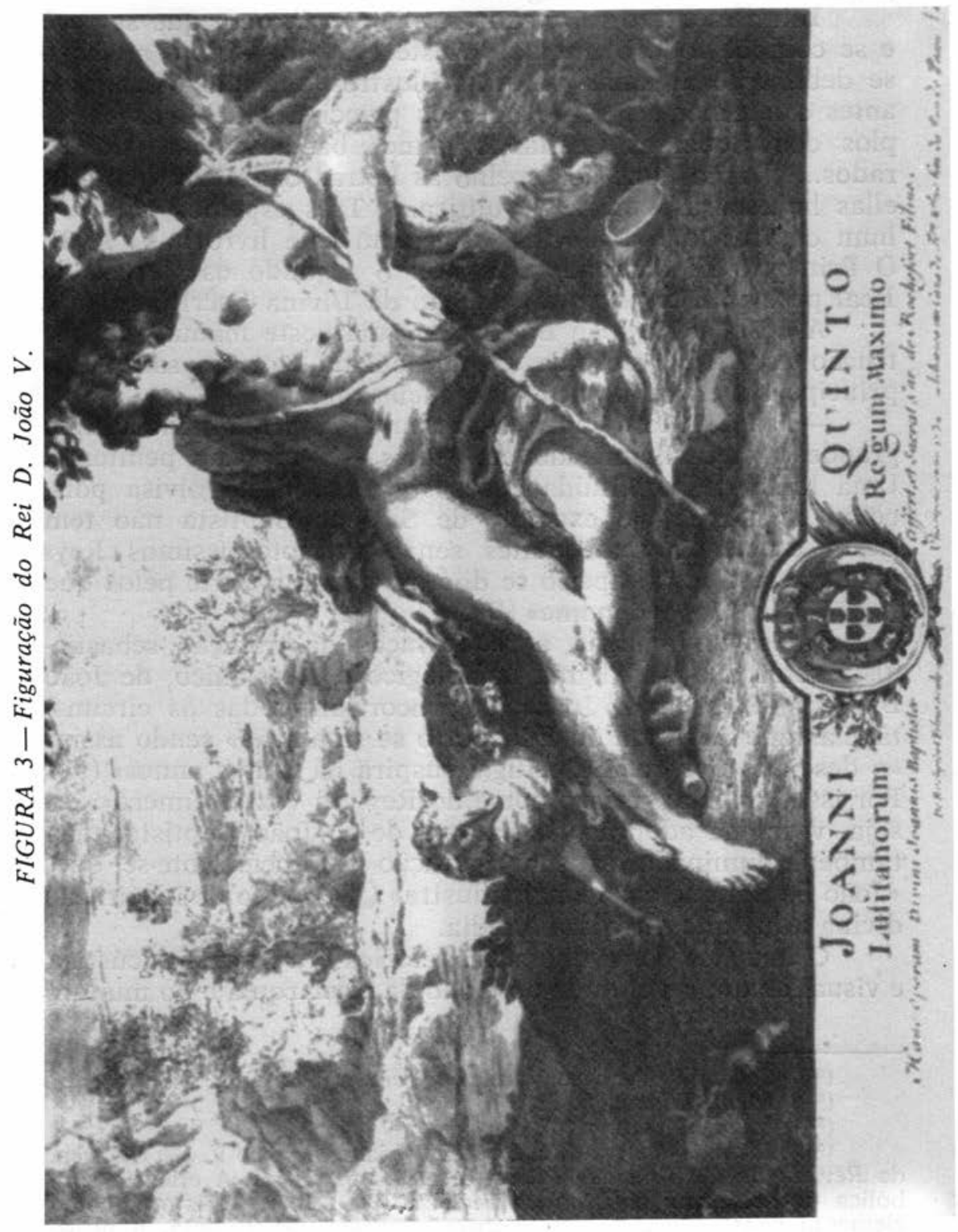


onde luzes e espelhos personificam figuras, iluminam, ampliam e refractam mensagens e valores.

Inicialmente o rei é um grande espelho em que se revê e se compõe todo o mundo. "Neste espelho - diz o autor se debuxarão algumas pinturas illustres que não offusquem antes o adornem.... serão aqui os principães debuxos exemplos dos Monarcas Lusitanos, nunca bastantemente ponderados.... Darão lume ao espelho as Letras Sagradas: que sem ellas he escura sombra a política.... Três espelhos pois, ou hum co tres circunstancias, offerecem este livro a V. A. R. O Primeyro he o grande Baptista: o segundo os Heroes da Real prosapia: terceyro a erudição da Divina Escritura» $\left({ }^{50}\right)$.

A lição de S. João Baptista é guia neste manual de instrução ascética e política. $O$ paralelismo entre o santo e o príncipe adverte-nos para duas ideias-força:

- Em primeiro lugar, a presença inspiradora do último grande profeta anunciado em Isaías - o messias penitente. Uma linha de continuidade se estabelece nesta divisa pois, como se afirma, "o exemplo de S. João Baptista não tem nesta excelencia semelhantes senão os potentíssimos Reys portugueses: cujo império se dilatou a toda a parte pelos que lograrão de João o nome» $\left({ }^{51}\right)$.

Em segundo lugar, a recuperação da tradição sebastianista reforça o paradigma hagiológico e messiânico, de João Baptista. Pois em D João V, «concorriam todas as circunstâncias que na vinda do Encoberto se sinalavão» sendo assim "O desejado por quem Portugal suspira há tantos annos» $\left({ }^{52}\right)$. Por isso "imortal seria o nome do Rey em voz e número», ou seja, vocal na adopção da palavra de S. João Baptista, mas também iluminado na sua figuração apolínea. Note-se que, «João he Sol que aos demais illustra» $\left({ }^{53}\right)$, sendo de inspiração divina a luz que a realeza irradia.

O que fica desta digressão retórica é a imagem acústica e visual de um rei elevado ao trono da monarquia e do mundo.

(50) Sebastião Pacheco Varela, ob. cit., pp. 15 e 16.

(51) Idem, ibidem, p. 23.

(52) Idem, ibidem, p. 47.

(53) Idem, ibidem, p. 216. Cf. Rui Bebiano, D. João V, Rei Sol, sep. da Revista de História das Ideias, 8, 1986, pp. 111-121. A eficácia simbólica do sol como símbolo da realeza de D. João V, isto é, como elemento constitutivo do seu discurso político não assenta, a nosso ver, na adopção mimética do modelo da monarquia absoluta de Luís XIV. Mais do que essa influência, ela expressa, bem ao jeito da sensibilidade barroca, a tensão entre o lado profano e sagrado da realeza, ou seja, a confluência entre o brilho terreno da sua presença 
A transposição simbólica do rei para a figura do santo persistirá, revelando o reverso de humildade e piedade de um monarca ostensivamente poderoso. Em 1732, uma água forte de Rochefort Fillius figura S. João Baptista descansando junto de uma oliveira, símbolo da paz e da perenidade, oferecendo a um cordeiro, colocado à sua direita, um ramo de oliveira. Sobre o braço esquerdo ostenta uma cruz com uma fita com a legenda «Ecce Agnus Dei». Ao fundo, um regato correndo mansamente separa esta margem de planície de uma outra montanhosa. Na parte inferior, ao centro, representa-se o escudo das armas reais e a inscrição: Joanni Quinto Lusitanorum Regus Maximo (figura 3) ${ }^{54}$ ).

Não será ainda por acaso que a última grande realização artística de vulto de $\mathrm{D}$. João $\mathrm{V}$ tenha sido a magnífica capela de S. João Baptista, erigida na igreja de S. Roque $\left({ }^{55}\right)$. Este último altar privilegiado da devoção do rei reforçava uma homologia que, ao precipitar-se na mentalidade colectiva, desembocava no sentimento partilhado do mártir.

Se a eficácia simbólica do martírio não se perde nesta transposição do herói idealizado para o homem terreno contribui. em todo o caso, para a banalização da imagem do rei, isto é, do miserável pecador e penitente que, no trono, depõe a coroa da realeza para abraçar, através da experiência do martírio, a da santidade.

Todo o sistema de representação do poder sai abalado com esta imagem. Afinal, o rei "taumaturgo" que, à seme-

e a luz oculta que dá sentido à inspiração divina e providencial da sua missão política.

Estamos porém conscientes que "os signos do poder não têm as mesmas áreas sociais de circulação e não implicam as mesmas regras de interpretação. Reconstituir essas diferenças (no acesso ao signo como nas possibilidades da sua «leitura». mais ou menos conforme à intenção que o produziu) é uma tarefa difícil, mas indispensável, para apreender, no campo da prática, a eficácia da simbólica do Estado. E que, «esta simbólica exprime-se também por meio de cerimónias, gestos e rituais", Roger Chartier, A História Cultural. Entre Práticas e Representações, Lisboa, Difel, 1988, p. 221.

(54) Ernesto Soares e Henriques de Campos Ferreira Lima, ob. cit., p. 208.

(55) Obra dos arquitectos italianos Salvi e Vanvitelli, a capela de S. João Baptista na Igreja de S. Roque tem merecido importantes estudos. Sousa Viterbo, Capella de S. João Baptista, Lisboa, Typ. da Loteria da Santa Casa da Misericórdia, 1900; Ayres de Carvalho, D. João $V$ e a Arte do seu tempo, vol. 2, Lisboa, ed. de autor, 1962; Maria João Madeira, «Aspectos de definição estética da Capela de S. João Baptista", Junta Distrital, Boletim Cultural, Lisboa, 1976, pp. 7-16; idem, "A Igreja de S. Roque de Lisboa - Proposta de interpretação», Junta Distrital, Boletim Cultural, Lisboa, 1970, pp. 5-26. 
lhança da realeza francesa $\left({ }^{56}\right)$, havia requerido ao Papa o indulto de poder ser ungido e sagrado transforma-se, no último decénio do seu reinado, num humilde penitente cujo exercício vivo de preparação da morte oferecia, como exemplo e troféu, aos seus súbditos.

A apropriação da imagem do rei em turpor de piedade data de 1742, altura em que a monarca é acometido de grave doença, prolongando-se até 1750, ano em que morre. Intervalo de tempo, demasiado longo para uma vida, que configura, exemplarmente, o modelo de agonia sofrida e prolongada bem característica dos grandes heróis da Contra-Reforma, como por exemplo, a de S. Francisco de Sales.

Ora, o exacerbamento da piedade do rei em torno da morte próxima apenas acentua a mundividência escatológica que caracterizava a cultura da corte joanina. Neste horizonte importa avaliar como e quem mais explorou esta imagem do rei, cuja expressão póstuma se consagraria em duas palavras -D. João V, rei Fidelíssimo e Magnânimo, isto é, fiel ao báculo e detentor de um poderio e riqueza que derramava em manifestações piedosas.

Note-se, em primeiro lugar, que esta leitura foi homologada por Roma através de um Breve Pontifício de 23 de Dezembro de 1748, em que se concede ao rei o título de Fidelíssimo, gesto decisivo para a imposição de uma imagem definitiva e póstuma, tanto do soberano como da monarquia portuguesa $\left({ }^{57}\right)$.

Um outro aspecto a reter prende-se com os mecanismos de reprodução na própria corte de símbolos, rituais e liturgias. De facto, a este nível, e no que concerne ao cerimonial e vivência da morte, parece ter ficado esboçada uma linha de

(56) Cf. Marc Bloch, Les Rois Thaumaturges. Etudes sur le caractère surnaturel attribué a la Puissance Royale particulièrement en France et en Angleterre, Strasbourg, Publications de la Faculté des Lettres de l'Université de Strasbourg, 1924. A sagração requerida por D. João V passou a ser conferida pelo patriarca de Lisboa, conforme estipula o Breve de Clemente XI de 26 de Setembro de 1720.

(57) Foram impressos e tiveram grande divulgação o Breve de 3 de Dezembro de 1748 e a Alocução do Papa Bento XIV no Consistório de 23 de Setembro de 1750. Breve do Santissimo Padre Bene. dicto XIV.... Pelo qual concede ao Serenissimo Rey de Portugal, e dos Algarves D. João $V$ e aos reis seus sucessores o título de Fidelissimo....., Lisboa, na Officina de Francisco Luiz Ameno, 1751; Allocução do Santissimo Padre Benedicto XIV. Aos Eminentissimos, e Reverendissimos Senhores Cardeaes da $S$. $R$. I., recitada no Consistorio Secreto em.... 23 de Septembro de 1750, Lisboa, na Officina de Joseph da Costa Coimbra, 1751; Cf. Francisco Xavier da Silva, ob. cit., pp. 122-127. 
continuidade entre a corte de D. Pedro II e a de D. João V. De uma forma mais ampla, as várias manifestações de cuitura nas duas cortes, que este trabalho concita, aguardam um estudo global e protundo. Da mesma maneira a intluência exercida pelo movimento religioso da jacobeia no Paço parece revelar-se um dado de grande relevância para a compreensao da piedade régia $\left({ }^{58}\right)$.

\section{As pompas fúnebres}

O confessor depositário da intimidade do rei e oráculo de verdades tornava-se uma figura chave na modulação da sua conduta, interferindo decisivamente na construção de uma imagem pública ${ }^{58}$ ).

Mas outros foram também os obreiros do manto piedoso que recobria a figura régia. Referimo-nos a um avultado número de ordens religiosas, congregações, confrarias e irmandades que, beneficiando ou não de legados apreciáveis, elegeram o anúncio da doença do rei em espectáculo contínuo de preces, procissões e até em momento ordálico de penitência colectiva.

Todas estas manifestações se iniciaram em Lisboa a 11 de Maio de 1742, por iniciativa da Igreja Patriarcal, cujo exemplo, com virtuosa emulação, como diz um contemporâneo, foi imitado em todas as províncias do Reino $\left({ }^{\circ 0}\right)$.

Com um enorme concurso popular, um interminável desfile piedoso decorreu, sem interrupção, na capital, entre 11 de Maio e 2 de Julho de 1742. Eram diárias as novenas e procissões de preces e muito frequentes as de relíquias e de penitentes, com realce para as dos religiosos de S. Francisco da Cidade, de Nossa Senhora do Monte do Carmo, dos religiosos do Convento da Graça e Irmandade do Senhor dos

(58) Sobre o Sigilismo, vide, Fr. António Pereira da Silva, A questão do Sigilismo em Portugal no século XVIII, Braga, Editor al Franciscana, 1964; L. Cabral Moncada, Mistica e Racionalismo em Portugal no séc. XVIII, Coimbra. Imprensa da Universidade, 1952; Manuel Augusto Rodrigues, $D$. Miguel da Anunciação e o Cabido da Sé de Coimbra, Separata do Vol. V do Boletim do Arquivo da Universidade de Coimbra, Coimbra, 1982; idem, Pombal e D. Miguel da Anunciação, Bispo de Coimbra, Sep. do vol. IV, da Revista de História das Ideias, Coimbra, 1982; Samuel J. Miller, Portugal and Rome c. 1748-1830. An Aspect of the Englightenment, Roma. 1978.

(59) Minois Georges, Le Confesseur et le roi. Les directeurs de Conscience de la monarchie française, Paris, Fayard, 1988.

( $\left.{ }^{\circ 0}\right)$ Diogo Barbosa Machado, Relaçam...., p. 14. 
Passos, uma das mais representativas da população de Lisboa, pois contava, ao tempo, mais de dois mil membros $\left({ }^{61}\right)$.

Este clamor piedoso e rogativo, ao fazer-se acompanhar da melhoria do estado de saúde do soberano, teve como contrapartida um exercício de liberalidade régia verdadeiramente assombroso. Basta referir a oferta e 5000 cruzados à Irmandade do Senhor dos Passos, com uma renda anual de 2000 cruzados e o nascimento de outro Palácio-Convento, o de Nossa Senhora das Necessidades $\left({ }^{62}\right)$.

(61) Refira-se que a irmandade do Senhor dos Passos da Graça era, na época, uma das mais prósperas e ricas da cidade de Lisboa. A irmandade que, na origem, se denominava de Santa Cruz e dos Passos foi instituída no século XVI. O seu florescimento está intimamente relacionado com o modelo de piedade que concitava, na linha da pastoral tridentina. Mas relaciona-se também com o crescimento e influência da gente de ofícios na cidade. Segundo um manuscrito coevo, a Irmandade do Senhor dos Passos contava em 1706 com 2000 confrades, que pagavam quatro mil réis de jóia e oitocentos réis por ano. Vide Ribeiro Guimarães, Summario de Varia Historia, Lisboa, Rolland \& Semiond, 1872, vol. I, p. 227.

(62) Conforme se pode ler em Joaquim Joze da Silva Brandam, Relaçam das Procissoens de Preces Publicas, que as Irmandades, Religoens, e mais clero desta Corte e Cidade de Lisboa, fizerão, pela Saude da Augusta Majestade Del Rey D. João V...., Lisboa, na Officina Joaquiniana de Musica de D. Bernardo Fernandez Gaio, s.d. Aí se registam cerca de duas centenas de iniciativas piedosas e rogativas que tiveram o concurso do povo de Lisboa. No final da sua descripcão o autor assinala: «Em o primeiro de Junho de 1742 se trasladou o Senhor dos Passos da Graça para a sua Capella acompanhado da sua Irmandade, e Religiosos do mesmo Convento, e dos Illustrissimos Prelados, Conego e Beneficiados, e mais Communidades da Santa Basilica Patriarcal, com a Guarda Real atraz da Procissão, que foy humas (sic) das funções mais devota, que tem vista, a espectação da Corte....

Em o dia de São João.... foy em Procissão, para a sua Igreja Nossa Senhora da Penha de França, que estava no Paço, no quarto de Sua Magestade, e tinha vindo a 17 de Mayo, cuja procissão acompanharão a sua Irmandade, os Religiosos da Graça, e a Santa Basilica Patriarcal, que a não acompanhou se não até o Polourinho, e sahio a Senhora de Palacio em hum Andor riquissimo, que se fez novo para a ditta função. A 2 de Julho se recolheo para a sua caza a Senhora do Monte do Carmo, que estava no Paço, cuja Procissão, os Illustrísssimos Prelados, Conegos e Beneficiados da Santa Igreja Patriarcal. Todas estas procissões se fizerão com tanta devoção, zelo e caridade, que bem se mostrou o amor dos Portugueses para com o seu Rey, e amante Pay, devendo este a algumas Communidades, a porem-se descalços pelas ruas em Procissão.... que mais, que as linguas pelas vozes, se explicavam os olhos pelas lagrimas....", idem, [p. 14]. Alguns dos muitos sermões recitados na ocasião, correram impressos e foram reunidos numa compilação com o título Collecção de todas as obras impressas por ocasião da ultima doença do Magnanimo Fidelissimo Senhor D. João V Rey de Portugal, Lisboa, 1763. 
Mas aquele clamor público não foi afã exclusivo da igreja. Muitos titulares da nobreza expressaram publicamente o mesmo sentimento. O melhor porta-voz deste timbre de sensibilidade aristocrática foi, sem dúvida, o Marquês de Valença $\left({ }^{63}\right)$.

A partir de então, e a conselho dos médicos da corte, multiplicaram-se as jornadas do rei às Caldas da Rainha. Nesse tempo em que a sua aparição pública se limitava cada vez mais aos locais de culto, estas deslocações, sem o brilho e a espectacularidade de anteriores apresentações régias, continuavam a ser motivo de grande atracção popular. 0 rasto de ouro que em cada viagem deixava pelo caminho assinalava $o$ destino final de um manancial de riqueza facilmente esbanjado. Esgotava-se, assim, a vida do rei e a riqueza do erário $\left({ }^{64}\right)$.

Num exercício derradeiro de simulação de uma pedagogia de penitência, o dia escolhido para o anúncio da morte do soberano foi o dia de Santo Inácio de Loyola, ou seja o dia 31 de Julho de $1750\left({ }^{65}\right)$. A ocasião fez esquecer a pragmática sanção de 24 de Maio de 1749, que moderava drasticamente despesas e gastos sumptuários. As cartas régias que assina-

(63) D. Francisco de Portugal e Castro, Elogio à constancia que El-Rey D. João $V$. Nosso Senhor tem tido na sua dilatada enfermidade.... Lisboa, na Officina de Miguel Rodrigues, 1748; vide ainda Proposiçam que a todas as Academias, e engenhos desta Corte, e de todo o Reino faz a Academia dos Escolhidos.... A melhora da Augusta Magestade d'el-Rey D. João V. Nosso Senhor, Lisboa, na Officina de Pedro Ferreira, 1747.

(64) «Nas jornadas que fazia às Caldas a tomar banhos distribuiu por todos aquelles povos muitas esmolas.... sendo sem número os que concorrião a solicitar este remedios", Francisco Xavier da Silva, ob. cit.; p. 287. Diogo Barbosa Machado acrescenta que «Nestas jornadas, que forão muitas, e em tempos diffrentes, distribuia thesouros aos pobres e religiosos, que de partes muy distantes concorriam a receber as copiosas esmolas....», ob. cit., p. 19. Cf. Vida e Sucessos, e Falecimento do Rey Fidelissimo D. João V. sl. i., s. d., p. 27.

(65) Diogo Barbosa Machado não pondo em causa a data do anúncio da morte do Rei não é claro nem suficientemente inequívoco. Curiosamente, a maior parte dos autores preferem e/ou sobrepõem à referência exacta do dia e do mês a menção ao «dia de Santo Inácio de Loyola». É, desde logo, muito sugestiva a associação sugerida por Frei Jacinto de S. Miguel, quando o rei adoeceu. A oito anos da sua morte, este clérigo interrogava: «E porque não patrocinará diante de Deos, e da Virgem Maria, Santo Ignacio esta causa, tão parecida com a Sua?", Sermão de Santo Ignacio de Loyola, Na Igreja de Nossa Senhora do Populo, na villa das Caldas.... Lisboa, na Officina de João Bautista Lero, 1742, p. 4. 
lavam a morte do monarca impunham a todo o povo dois anos de luto pesado $\left(^{(8)}\right)$.

O compasso de espera entre a morte e a sepultura na Igreja de S. Vicente de Fora foi, ao contrário do que era costume em cerimoniais fúnebres solenes, abreviado. Mesmo assim, no espaço de 4 dias, rezaram-se 6000 missas de corpo presente pela esmola elevadíssima de 1 cruzado. No oitavo dia, com a mesma esmola, prescreveram-se em todas as igrejas do reino 18000 missas. Tudo isto para além dos incontáveis ofícios solenes recitados em vários conventos $\left({ }^{67}\right)$.

O paço cobriu-se de negro exibindo uma atmosfera lúgubre aberta, todavia, ao brilho e à irrealidade dos amarelos oura e dos vermelhos ardentes. Neste cenário cromático, avivado por largas centenas de tochas e brandões a arder, desenrolar-se-ia o último cumprimento de cortesia da nobreza e do clero. Lá fora, como relata Diogo Barbosa Machado, repetiam-se «de quatra em quatro tiros de canhão, que se disparavão no castelo e baluarte da vedoria, cujo estrondo unindo-se ao que fazião todos os sinos da cidade e ao toque das trombetas à surdina dos regimentos da cavallaria, e caixas destemperadas cobertas de luto da Infantaria, rompendo os ares penetravam os corações com tão sensivel dor que Lisboa não vio em muitos annos dia mais triste e lamentavel» $\left({ }^{68}\right)$.

O cortejo fúnebre desenrolar-se-ia entre o Paço da Ribeira e S. Vicente, durante a noite, com o mesmo aparato sonoro e intensa visualidade, com a cavalaria alinhada no Terreiro do Paço, a «infantaria pelas ruas, toda com as suas

(68) Este prolongado luto corresponde a um ano de exéquias na metrópole e no Império. As últimas manifestações luctuosas, com construção de mausoléu, ocorrem em Goa, a 14 de Novembro de 1751. Vide Noticia Chronologica dos Funeraes que as cidades e villas do Reino de Portugal dedicarão...., Madrid, En la Imprenta de Antonio Perez de Soto, 1752; Robert C. Smith, Os mausoléus de D. João $V$ nas quatro partes do mundo, Separata da Revista da Faculdade de Letras de Lisboa, tomo XXI. 2.: Série, n. 1, Lisboa, 1955; Ribeiro Guimarães, $o b$. cit., vol. 2, pp. 133-136.

(67) Diogo Barbosa Machado, ob. cit., pp. 33 e 34. Cf. Francisco Xavier da Silva, ob. cit., p. 340; Memoria das Exequias Solemnes, que até o presente se tem celebrado nesta corte, e mais partes do Reino pela alma do Fidelissimo....; s. 1 s. d.; Noticia Chronologica dos Fune. raes....; A.N.T.T., Manuscritos de S. Vicente, vol. 23, t. 26.

(88) Diogo Barbosa Machado, ob. cit., pp. 37 e 38. 
armas rendidas», tendo à sua frente todas as ordens religiosas e clerezia da cidade que empunhavam velas a $\operatorname{arder}\left({ }^{(0)}\right)$.

Mas as exéquias régias, segundo uma tradição, cujas origens importaria conhecer melhor, eram também assinaladas na capital, como em todas as comarcas, por um cerimonial laico, protagonizado pelos Senados das Câmaras e assistido por numeroso povo que bem alto carpia a memória do rei. Era uma cerimónia muito prolongada e concorrida a que se dava o nome de "quebra dos escudos» $\left({ }^{70}\right)$.

No caso de D. João V o desfile saiu da Casa do Senado, no Rossio, precedido por um procurador montado a cavalo, envergando pesado luto e ao ombro uma haste negra da qual pendia uma bandeira enorme que se arrastava pela rua. Logo a seguir, repartidos por duas alas, dois corpos de homens-bons

(9) Idem, ibidem. Este enquadramento cénico do fasto fúnebre da realeza adequa-se perfeitamente ao cerimonial barroco da morte dos grandes Vide Michel Ragon, L'Espace de la mort. Essai sur l'architecture, la décoration et l'urbanisme funéraires, Paris, Albin Michel, 1981; Michel Vovelle, ob. cit., pp. 315-321; Idem, Mourir autrefois, les attitudes devant la mort aux XVII'e $\mathrm{e} X V I I I^{e}$ siècles, Paris, 1974; André Chastel, «Le Baroque et la mort», in Atti del II Congresso Internationale di Studi Umanistici, Veneza-Roma, 1955; Santiago Sebastião, Contra Reforma e Barroco, Madrid, Alianza Editorial, 1981.

$\left.{ }^{70}\right)$ Uma das mais antigas figurações desta cerimónia encontra-se no Livro de Horas de D. Manuel (Estudo introdutório de Dagoberto Markl), Lisboa, Imprensa Nacional-Casa da Moeda, 1983, fl. 129v e 130. Cf. João Baptista de Castro, Mappa de Portugal Antigo e Moderno, Tomo Primeiro, partes I e II, Lisboa, na Officina Patrarcal de Francisco Luiz Ameno, 1762, pp. 446-448. Remontando às origens do escudo de Afonso Henriques. José Mattoso admite que a sua veneração está ligada ao acto de aclamacão do rei de pé sobre o pavês, ou seja a um ritual guerreiro e a uma cerimónia civil. (J. Mattoso, «A Realeza de Afonso Henriques», in Fragmentos de uma Composição Medieval, Lisboa, Editorial Estampa, p. 227 a 229). Ora não podemos deixar de assinalar que, mais tarde, a utilização do escudo como signo de identidade, que se quebra publicamente em sinal de luto, prolonga numa cerimónia também civil a fidelidade da Nação à realeza. Por outro lado, se associarmos o testemunho do Livro dos Arautos, que contém uma das primeiras descrições da quebra do escudo junto ao túmulo d'Afonso Henriques, ao de Manuel Severim de Faria quando refere que na igreja de Santa Cruz, em Coimbra, $\propto$ Em hũa capella da Sanchistia se guarda inda o seu [de Afonso Henriques] escudo do qual dizem que estando pendurado cahia no chão em o dia que morria qualquer Rey deste Reyno, e que quando se perdeo a batalha de Alcaçere cahio se fez em pedaços», (in Viagens em Portugal de Manuel Severim de Faria, Lisboa, 1974, p. 100, cit. in Diogo Ramada Curto, O Discurso político em Portugal (1600-1650), Lisboa, Projecto Universidade Aberta, 1988), poderemos admitir a hipótese de estarmos perante um ritual que rompeu o espaço fechado da igreja e se instalou no espaço profanizado e aberto da cidade. 
e magistrados, também com capas compridas e varas pretas nas mãos. Ao meio, postavam-se três juízes dos órfãos da repartição da cidade, cada um com o seu escudo negro. Atrás seguiam os restantes oficiais e vereadores do Senado da Câmara.

O cortejo seguia a compasso parando em três pontos-chave do percurso. Logo na Praça do Rossio, depois na Rua Nova do Almada e, por fim, defronte da Igreja Patriarcal, em vez do tradicional largo da Sé. A escolha e até a ordem de sucessão destes espaços conferem um sentido inicial à linguagem simbólica do cerimonial. Neles se ritualiza o último exercício de obediência e fidelidade das três ordens do reino à realeza, com especial destaque para o povo e burguesia urbana, representados em dois lugares de eleição. a Praça do Município, ao Rossio, e a rua Nova dos Mercadores, também designada Rua Nova do Almada.

Em cada um destes espaços se tinham erguido estrados cobertos de preto. Aí, um dos juízes erguia a voz e proclamava: "Chorai Nobres! Chorai Povo que morreo o vosso Rei D. João V de Portugal», e imediatamente, no meio de copiosas manifestações de pesar, quebrava o seu escudo. Acto simbólico muito curioso que prolonga no sacrifício dos escudos quebrados a sucessão régia. Os escudos. "brazão e troféu de glória da monarquia", ao quebrarem-se ficavam, como nos diz um contemporâneo. "como despojo enternecido do poder inexoravel da morte» $\left({ }^{71}\right)$.

Foi, no entanto, nas igrejas e conventos que o espectáculo da morte régia se exprimiu com mais arrebatamento.

Por toda a parte se erigiram cenotáfios ou mausoléus, alguns descritos como "autênticas maravilhas do mundo" $\left({ }^{72}\right)$. No de Braga, assim descrito, gastaram-se 80 arrobas de cera. Em Lisboa, ergueram-se cerca de meia centena de catafalcos e mausoléus. O que se ergueu na Sé de Lisboa integra-se na tradição da arquitectura académica barroca (figura 4) $\left({ }^{73}\right)$.

Esteticamente mais inspirado no gosto renascença, foi o mausoléu construído na Sé de Viseu (figura 5). Apesar das variações de estilo, ambos revelam um mesmo espírito decorativo marcado pela presença de esqueletos, prateados e

(71) Francisco Xavier da Silva, ob. cit., p. 343.

$\left.{ }^{72}\right)$ Rodrigo Joseph de Faria, Relaçã̃o das Exequias que na Morte Del Rey Fidelissimo.... mandou fazer na cathedral de Braga o serenissimo Senhor, Dom Joseph....; Lisboa, na Officina Sylviana e da Academia Real, 1755 , p. 5.

(73) Robert C. Smith, ob. cit., pp. 10 e 11. 
Morte, memória e piedade barroca

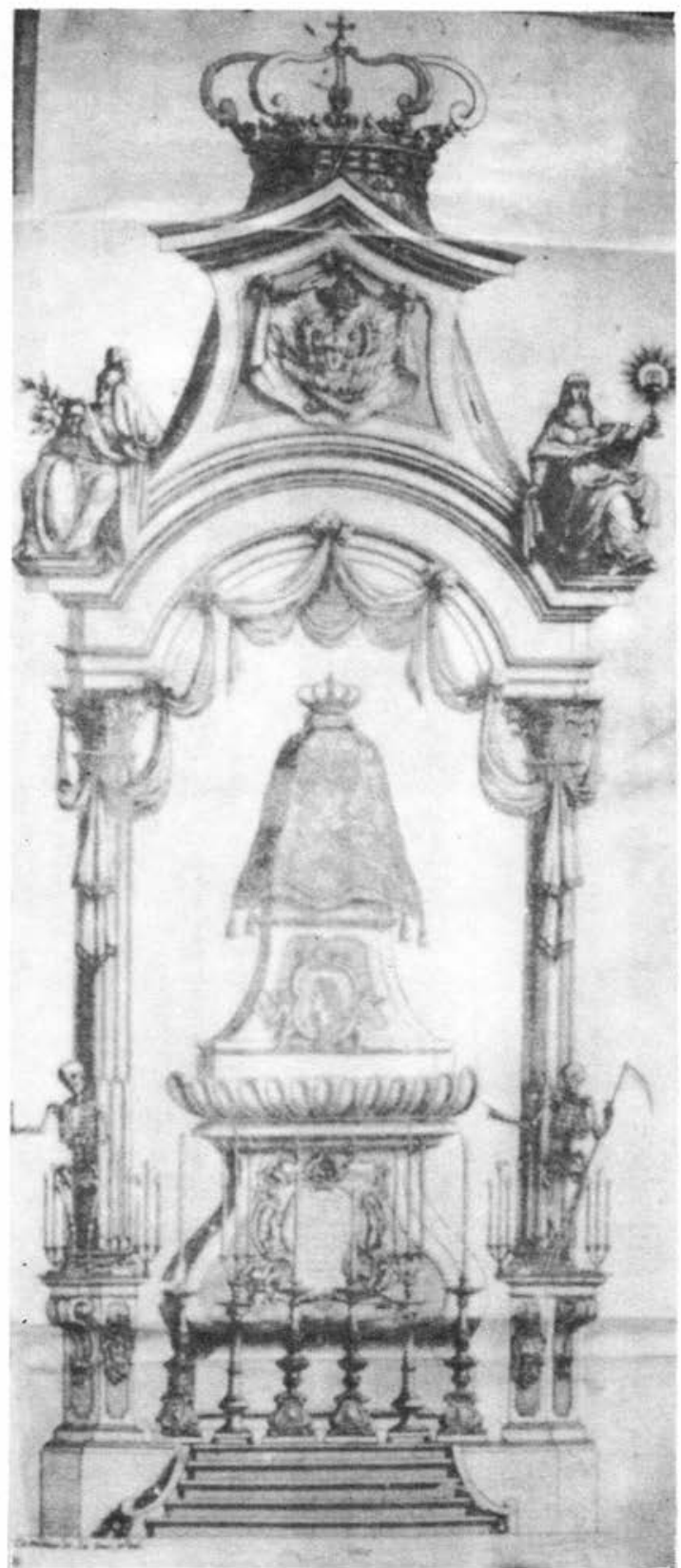

FIGURA 4-Mausoléu de D. João V na Sé de Lisboa 
Revista de História das Ideias

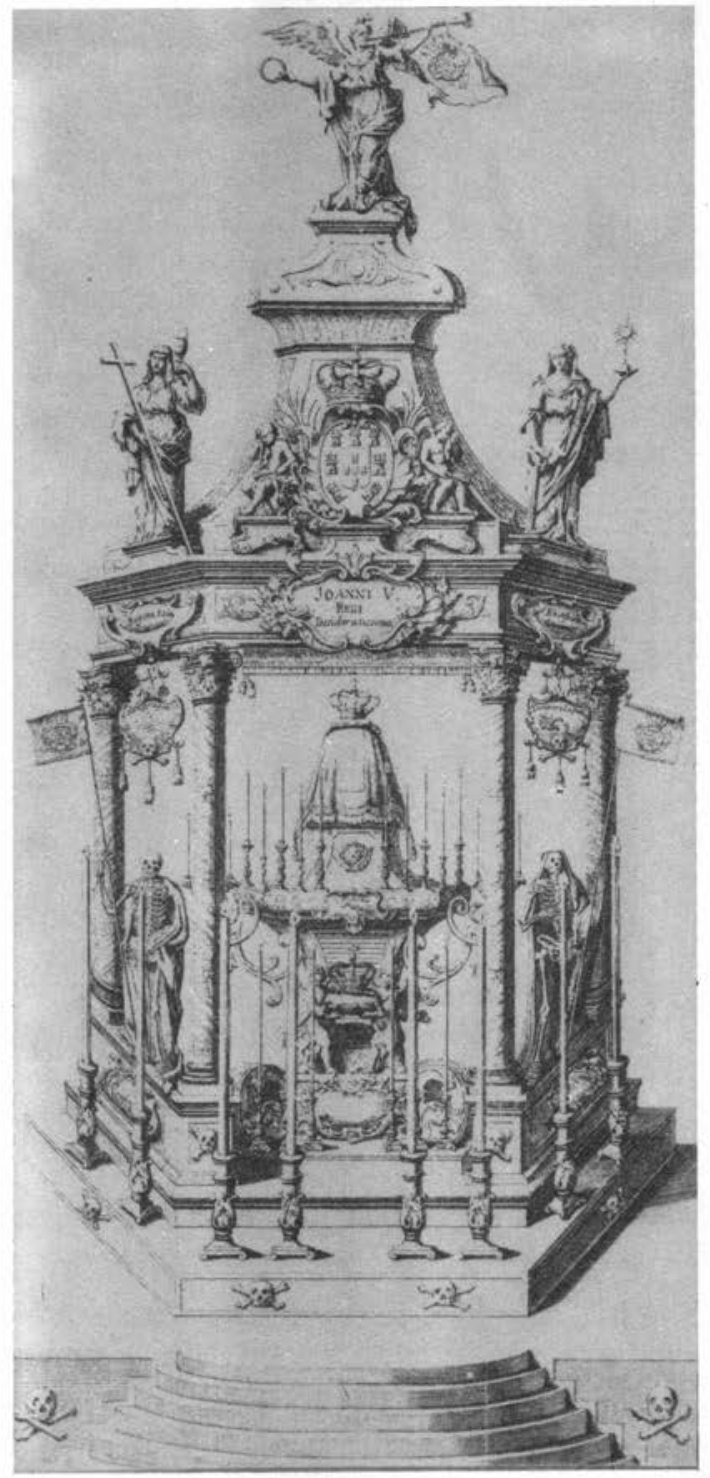

FIGURA 5-Mausoléu de D. João V na Sé de Viseu 
dourados e por outros símbolos macabros como a foice e a ampulheta. Para além, é claro, do ambiente em que se enquadravam, cuja decoração semelhante mais enfatizava esta representação teatral e pateticamente macabra do Castrum Doloris.

Paradigma da arte mineira, e ostensivamente macabro, era ainda o catafalco construído na Matriz de S. João d'El-Rei. na Comarca de Rio dos Mortos, em Minas Gerais, (figura 6) ( $\left.{ }^{74}\right)$. Compunha-se de quatro corpos, assentes em oito quartões ou pernas formadas de volutas. Ao lado, sobre quatro plintos, erguiam-se com bastante realismo, movimento e expressão quatro esqueletos vestidos com o manto da Ordem de Cristo. O mausoléu era coberto por uma cúpula e pavilhão sustentados por quatro grandes colunas coríntias decoradas.

No primeiro corpo central do catafalco representava-se uma nau, descrita como nau da morte, surgindo dos abismos do oceano e elevando-se até ao céu com a inscrição $E$ tumullo ad coelum.

E curiosa, e prende-se com o imaginário da época, esta associação entre o mar e a morte, como em outra parte já notámos. Em cima, figura-se a «Águia portuguesa, desprezando a fragilidade do mundo, illustrando-se na paz do divino Sol» $\left({ }^{75}\right)$.

Fora do espaço nacional, foi em Itália que as pompas fúnebres de $\mathrm{D}$. João $\mathrm{V}$ revestiram maior solenidade e lustre. De facto, Roma permanecia, desde o século XVI século do Concílio de Trento, como o lugar privilegiado das grandes demonstrações fúnebres $\left({ }^{78}\right)$.

$\mathrm{Na}$ decoração dos cenotáfios e na mise en scène do espectáculo, a tradição de Bernini mantinha-se viva ainda em alguns círculos.

Ora, as exéquias à magestade Fidelíssima tiveram lugar na igreja de Santo António dos Portugueses, na presença do Cardeal Corsini. A decoração lúgubre da igreja combinava

(74) Vide Adalgisa Abrantes Campos, «A presença do macabro na cultura barroca», Revista do Departamento de História, Minas Gerais, Dezembro de 1987, pp. 83-90. A gravura do catafalco da Igreja de S. João d'El-Rei aparece em. Mathias Antonio Salgado, Monumento de Agradecimento, Tributo da Veneranças oblisco funeral do obséquio, Relaçam fiel das reaes exequias.... da Matriz de N. Senhora do Pillar da Vila de S. João del Rey...., Lisboa, na Officina de Francisco da Silva, 1751.

(75) Mathias António Salgado, ob. cit., p. 7.

(78) Vide Michel Ragon, ob. cit., p. 176 e ss. 
Revista de História das Ideias

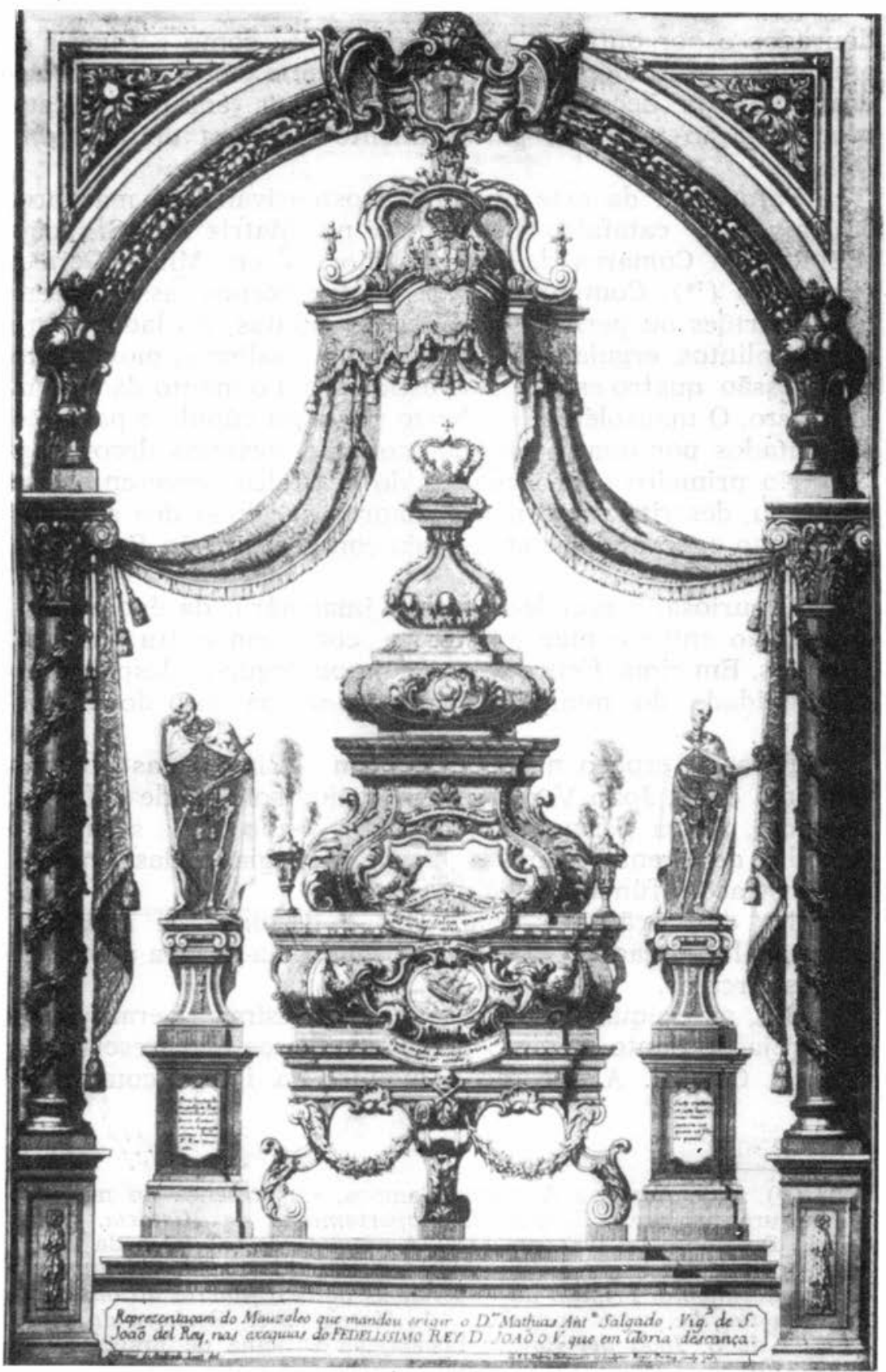

FIGURA 6-Mausoléu de D. João $V$ na Matriz de S. João d'El-Rei, em Minas Gerais. 
Morte, memória e piedade barroca

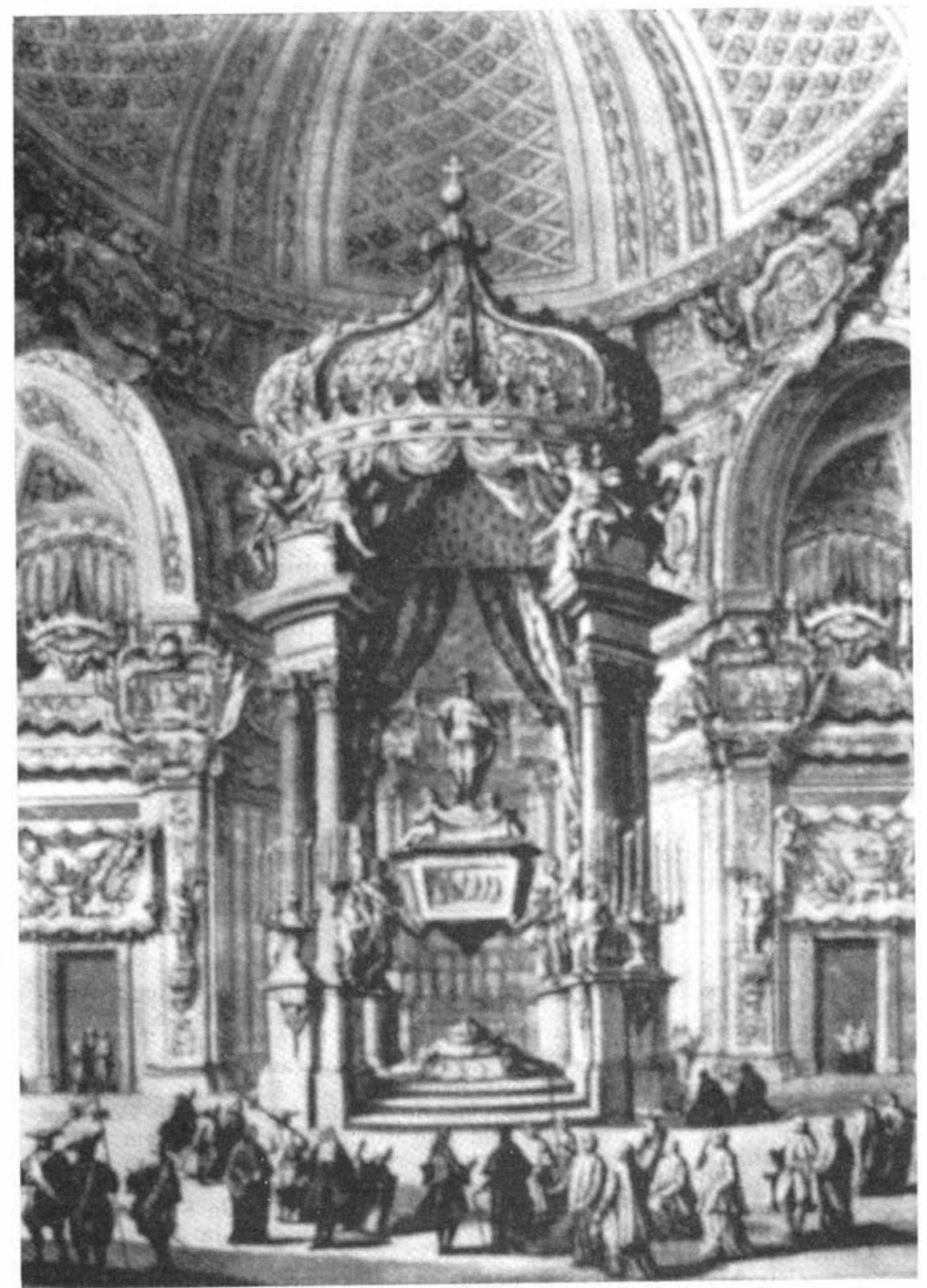

FIGURA 7 - Castrum Doloris de D. João $V$ na Igreja de Santo António dos Portugueses, em Roma. 
com o cenotáfio erguido no cruzeiro, que imitava um templo em figura oitavada sobre oito colunas insuladas das quais nasciam quatro ângulos imaginários (figura 7). A urna, num aparato tipicamente barroco, era representada suspensa, suportada por quatro estátuas de estuque, simbolizando as quatro partes do mundo, numa alusão clara ao império colonial português. Os seus baixos relevos figuravam alguns acontecimentos do reinado de $\mathrm{D}$. João $\mathrm{V}$ de maior projecção em Roma. Como salienta R. C. Smith, "todas as estátuas de estuque foram desenhadas por Pedro Bracci, o maior imaginário de então; as figuras da fama, no parapeito da cornija são de autor diferente, lembram pela posição, que ocupam e pelos seus animados gestos, os anjos de Bernini e António Raggi nos templos seiscentistas» $\left({ }^{77}\right)$.

No faustoso cerimonial fúnebre em Roma, recitaram-se alguns sermões, entre os quais um da autoria de Luís António Verney $\left({ }^{78}\right)$.

E, aliás, vastíssimo o número de relatos, memórias, epicédios, orações e prantos poéticos publicados na época, a propósito dos fastos fúnebres do monarca $\left({ }^{79}\right)$.

Foi necessário percorrê-los para captar a cenografia do verdadeiro espectáculo e respeitá-los como fontes da morte sentida e observada para evidenciar os traços mais vincados de uma sensibilidade colectiva.

No termo desta reconstrução verificámos que, numa sociedade marcada por uma forte tensão escatológica, a morte

(77) Robert C. Smith, ob. cit., pp. 18-21.

(78) Oração de Luiz Antonio Verney, Cavalleiro Torquato, Arcediago de Evora, na morte de D. João V. Rey Fidelissimo de Portugal, aos Cardeaes. Traduzida do idioma Latino no Portuguez por Theotonio Montano; Accresce huma Carta deste mesmo Traductor, sobre a Tradução. Lisboa, na Regia Officina Sylviana, e da Academia Real, 1752. Vide também Oração nas exequias do Fidelissimo Rey de Portugal D. João V. Que em nome de Sua Magestade se celebrarão na Igreja de S. António da Nação Portugueza, recitada por Sebastiam Maria Correa, Prelado Domestico de S. Santidade, e Presidente da Capela Real da mesma Nação. Traduzida por Manoel Carlos da Silva, Lisboa, na Officina de Francisco Luiz Ameno, Impressor da congregação Cameraria da S. Igreja de Lisboa, 1752.

(79) A grande maioria destas espécies encontra-se coligida em uma Colleçam das obras que se imprimiram por occasiam da Morte do Fidelissimo e Augustissimo Senhor D. João $V$ Rey de Portugal, Lisboa, Anno de 1763 (7 volumes). B.G.U.C., Miscelâneas 66 a 72. 
dos grandes, da agonia ao cerimonial, era objecto de uma publicidade chocante. Como projecção das aspirações pastorais e pedagógicas da igreja, a sua eficácia era enorme porque, sendo o cerimonial um acto público, e exemplarmente vivido, produzia um efeito quase "hipnótico". Efeito que se consubstanciava numa visão simultaneamente «longa e próxima», num exercício repetido de simulação e idealização da morte.

A ostentação, sinal de uma "exemplaridade visível», corporiza um modelo de piedade que, inflacionando o gesto, valoriza o excesso retórico. Através de uma linguagem simbólica complexa, o cerimonial da morte do rei recapitula velhos mitos e sinais de grandeza do passado, ou seja, o que não morre. De algum modo, aquela evocação reforça, por contraste, a aguda consciência da condição frágil e efémera do homem.

No seu momento mais alto o cerimonial da morte, potenciando a celebração da memória individual, impõe o reconhecimento social e colectivo da História, pelo menos de uma certa concepção de História.

Assinale-se, por fim, que "a morte dos grandes, com a sua rígida etiqueta é apenas uma variante de um modelo que vai encontrar nos conventos, entre os religiosos mortos em odor de santidade, os seus exemplos mais edificantes" $\left({ }^{80}\right)$.

Neste quadro, a morte de D. João V, enquanto ocasião que se dá imediatamente a ver, mas também pelo paroxismo emocional que concita, é expressão eloquente de um ethos e de uma sensibilidade colectiva.

Esta zona de claridade projecta a representação da figura do rei em toda a sua complexidade. De facto, ler a realeza presente e ler a realeza ausente é algo que, desde logo, diferencia e pluraliza a sua imagem.

Por fim, não podemos deixar de assinalar os traços grotescos com que a historiografia positivista dos séculos XIX e XX, embora apta a demonstrar a autenticidade das fontes e dos factos, recobriu a figura de D. João V, emparedando-a entre o convento e a alcova.

Hoje sabemos que, mais do que este aspecto burlesco, o silêncio lançado sobre a época de $\mathrm{D}$. João $\mathrm{V}$ denuncia a própria impossibilidade e a incapacidade de uma historiografia.

(80) Michel Vovelle, La Mort de l'Occident...., p. 324. 